Dunnicaer, Aberdeenshire, Scotland: a Roman Iron Age promontory fort beyond the frontier

Gordon Noble ${ }^{\mathrm{a} *}$, Nicholas Evans ${ }^{\mathrm{a}}$, Derek Hamilton ${ }^{\mathrm{b}}$, Cathy MacIver ${ }^{\mathrm{c}}$, Edouard

Masson-Maclean ${ }^{\mathrm{a}}$, and James O’Driscolla .

With contributions by: Gemma Cruickshanks ${ }^{\mathrm{d}}$, Fraser Hunter ${ }^{\mathrm{d}}$, Dominic Ingemark ${ }^{\mathrm{e}}$, Ingrid Mainland ${ }^{\mathrm{f}}$, Simon Taylor ${ }^{\mathrm{g}}$ and Colin Wallace ${ }^{\mathrm{h}}$.

${ }^{a}$ University of Aberdeen $*_{\text {g.noble@ abdn.ac.uk }}$

${ }^{\mathrm{b}}$ SUERC, University of Glasgow

${ }^{c}$ AOC Archaeology, Inverness

${ }^{\mathrm{d}}$ National Museums Scotland

${ }^{\text {e }}$ Uppsala University

${ }^{\mathrm{f}}$ University of the Highlands and Islands

g University of Glasgow

${ }^{\mathrm{h}}$ Independent Researcher 


\title{
Dunnicaer, Aberdeenshire, Scotland: a Roman Iron Age promontory fort beyond the frontier
}

\begin{abstract}
Dunnicaer, Aberdeenshire, a now isolated sea stack, is the findspot of five Pictish symbol stones discovered in the nineteenth century. Excavations from 2015 to 2017 have revealed a Roman Iron Age promontory fort, providing insights into the development of fortified settlement in north-east Scotland, with fortified sites being a key feature of first millennium AD elite practice in this region. The presence of rare and unusual finds indicates contact with the Roman world to the south and changes in the character of settlement as evidenced at Dunnicaer indicate broader transitions in the later Roman Iron Age native society. The archaeological sequence at Dunnicaer sheds new light on the adoption of non-roundhouse styles of architecture in first millennium $A D$ Scotland and provides important evidence for the dating of the Pictish symbol tradition. A consideration of the impacts of coastal erosion on promontories of this nature suggests these are amongst the most threatened archaeological sites.
\end{abstract}

Keywords: Pictish; Roman Iron Age; fort; settlement; symbol stone; coastal erosion

\section{Introduction}

[Figure 1 near here]

Dunnicaer (NRHE No. 37001; NO 8821 8464) is a precipitous sea stack on the coast of Aberdeenshire, just south of Stonehaven (Figure 1). In the nineteenth century a group of youths found a low stone wall on the top of the stack and threw a number of carved 
stones found within the wall into the sea (Thomson 1859, 70). These stones (Figure 2) were subsequently identified as Pictish symbol stones and the Dunnicaer examples have often been mooted as early examples in the Pictish symbol tradition (e.g. Alcock 1996, 2003, 372; Henderson and Henderson 2004, 171; Noble et al. 2018, 1334). Dunnicaer is located in a bay just to the north of Dunnottar Castle, a site that has references going back to the seventh century AD (Fraser 2009, 214). Few people had visited Dunnicaer since the nineteenth century, but three seasons of fieldwork by the University of Aberdeen Northern Picts project (2015-17) identified the very substantially eroded remains of a promontory fort with a timber-laced or framed rampart. Inside the rampart, contemporary buildings and hearths were identified. Finds included Roman Samian and coarse-ware and glass; all rare imports this far north of the frontier, along with burnishing stones for metalworking. Radiocarbon dating has provided a firm chronology for occupation throughout the Roman Iron Age. This article provides a detailed account of the excavations, specialist reports on the finds and dating and a detailed discussion on the significance of the discoveries. In particular, the discussion focuses on the implications of the excavations for changing architectural traditions in north-east Scotland from the third century AD onwards, the dating of the Pictish symbol tradition, the significance of the Roman finds far north of the frontier and the function and context of the site.

[Figure 2 near here]

\section{The nineteenth century discovery of the symbol stones at Dunnicaer}

John Stuart in his seminal volume Sculptured Stones of Scotland (1856) was the first to record Dunnicaer and two of the Pictish symbol stones that came from the sea stack. In his book Stuart wrote: 
The fragments [the symbol stones] at Stonehaven are said to have formed part of a wall which surrounded the top of an insulated rock called Dinnacare [sic], standing at no great distance from the shore, about a mile and a half to the south of Stonehaven. They are now in the possession of the Keeper of the Gas Work at Stonehaven, who found them at Dinnacare about sixteen years ago. There were other similar fragments which have since disappeared. One of them is supposed to form the hearthstone of the house of James Brown, Fisherman, Stonehaven. (Stuart 1856, 14).

Having seen these stones in Stuart's volume, an Aberdeenshire antiquary, Alexander Thomson of Banchory, set out in 1856 to investigate further. Thomson first purchased the two stones recorded by Stuart, Dunnicaer No.1 and No.2, from Mr Ross, the gasworks manager at Stonehaven, which he recounted in his publication on the site (Thomson 1859). In Thomson's account the circumstances of the discovery of the Dunnicaer stones are recorded via a published letter from James Christian, a local writer from Stonehaven (Thomson 1859, 74-75). Christian recounts that in $1832 \mathrm{Mr}$ Ross and two or three companions had 'set out on a frolic' along the coast, climbing up to the top of the Dunnicaer sea stack. The ascent was noted as being difficult and dangerous. Their visit was said to have been prompted by a local man, Blair, a grave-digger, who had recurring dreams that there was a concealed cave on top of the sea stack where a great quantity of gold was hidden. Unfortunately for the youths they did not find gold, but reported discovering a buried wall when they dug into the top of the sea stack. The low wall was 'along part of the edge' and was 'regularly built' (Thomson 1859, 70, 74). Once the wall was discovered, the youths proceeded to throw some of the stones from the wall into the water, but noted that some of them were carved. The next day, Mr Ross removed one stone (Dunnicaer No.1) to his house. 'Many years afterwards, when 
sculptured stones began to be talked of' he returned to Dunnicaer and recovered another (No.2). No.2 was completely covered in seaweed, but found to be in 'tolerable preservation' (Thomson 1859, 70).

Acting on Christian's account, Thomson set out to find other fragments and requested that Mr Christian send out men to the spot at low tide to search. They did so on two occasions and found two further stones: Dunnicaer Nos.3 and 4. Thomson himself tried to visit in July 1856 when the tide was very low. He was accompanied by Mr Tindal, procurator-fiscal for the county of Kincardine (now part of Aberdeenshire). He was disappointed to find that the access was such that it was too dangerous and difficult to get up.

Thomson retrieved one further stone from the village of Stonehaven. The stone (Dunnicaer No.5) had been taken for building stone by a Mr James Brown, a fisherman in the village of Stonehaven. After some effort, James Christian had retrieved the carved stone from Mr Brown's house for Thomson. Christian in his letter to Thomson remarks that local people knew Dunnicaer as a place where building stone could be obtained, suggesting stonework was eroding out of the stack and that there was extensive robbing of the site for stone throughout the nineteenth century (and probably earlier).

\section{The Stones}

[Table 1 near here]

There are five carved stones surviving from Dunnicaer today (RCAHMS 2008, 20-21) (Table 1). Nos.1-4 still stand in the grounds of Beannachar House (on the south side of Aberdeen) (NRHE No. 20282, NJ 9156 0246), with the fifth held at Marischal Museum, University of Aberdeen (Figure 2). The stones are part of a tradition of Pictish symbol stone monuments, of which there are over 200 surviving from eastern and northern Scotland (RCAHMS 2008). The Dunnicaer stones are of the incised, Class I, tradition, 
generally unshaped stones carved with a distinctive group of symbols, some abstract, others naturalistic, for example crescents or discs, animal designs such as fish or boars, or objects such as mirrors, and combs (Allen and Anderson 1903, 200-1; Henderson and Henderson 2004, 167). The distribution of symbol stones closely matches the extent of the Pictish kingdoms as reconstructed from the limited historical sources we have and from place-names (e.g. Wainwright 1955b, 43). The Dunnicaer stones are relatively roughly carved compared to some of the more accomplished monuments, with the stones often identified as being towards the beginnings of the tradition (e.g. Alcock 1996, 2003, 372; Henderson and Henderson 2004, 171; See below). The stones generally have one symbol rather than the more normal pairs, but No.5 has carvings on two sides of the stone. The stones are of a different character with two on subrectangular blocks of stone, two on water-worn boulders (No. 2 and 4) and No.1 forming an irregular, probably quarried, block. The symbols have been made by both pecking and incision.

Thomson's account refers to other stones at Dunnicaer that no longer survive. One additional stone is illustrated in Stuart (1867, Plate XV), but it may not be part of the same collection. This stone is said to have measured approximately $0.12 \times 0.11 \times 0.1$ $\mathrm{m}$ and was 'rudely sculptured on all four sides'. Stuart's drawings suggest a stone of very different character to the other Dunnicaer stones with small incised marks on four sides, none of which closely resemble Pictish designs. The origin of this stone is also ambiguous - Thomson $(1859,73)$ says that:

'It was sent to me by Mr Smith, postmaster, Old Aberdeen, in consequence of the discussion of the subject which took place at the Spalding Club in June last. It was found by him as one of the building, or rather packing, stones of an old clay-built wall taken down by him a few years ago.’ 
From this account it does not sound as if it was found on the stack or indeed necessarily at Stonehaven, for Thomson writes on the same page that:

'The most important matter in connexion [sic] with this little relic is the proof which it gives that these remains may occur in any old wall. No place could be more unlikely than the wall of an old cow-house, built together in the rudest manner.'

Thus, it seems unlikely that this was a symbol stone, but whatever its exact origins it is now lost and no other carved stones have been recovered from Dunnicaer since the nineteenth century discoveries.

The symbol stones from Dunnicaer have attracted interest since the midnineteenth century. Stuart $(1856,1867)$ and Thomson $(1859)$ were the first to record the stones, but they did not interpret their function or character in any particular way, nor speculate on their date. In Allen and Anderson's The Early Christian Monuments of Scotland (1903, 200-201) the symbol stones from Dunnicaer were described, but were said to have been lost. Allen and Anderson described the stones as of being a "primitive type', along with examples from Rhynie, Inverurie, Inveravon, Logie Elphinstone, and Kintore, all Aberdeenshire, and Kintradwell and Littleferry from Sutherland, also proposed to show early forms of symbol design (Allen and Anderson 1903, cv-cvi). In referring specifically to Dunnicaer No. 3, decorated with a crescent and triangle, Allen and Anderson suggested that this design may/might represent the earliest form of the crescent and V-shaped rod symbol with the triangle a forerunner of the V-rod design. In 1915 James Ritchie 'rediscovered' the stones from Dunnicaer at Beannachar House. He did not muse on the dating or function of the stones, but noted for the first time the presence of an additional symbol carved on the back of Dunnicaer No.5 (Ritchie 1915, $34)$. 
In some major publications in the second half of the twentieth century on the dating, origins and functions of Pictish stones, the Dunnicaer examples received surprisingly little comment. They were mentioned only in passing by Henderson (1958) in her discussion of the origins of the symbol tradition and only briefly in Thomas' (1963) interpretation of the Pictish stone tradition, and did not appear at all in Laing and Laing's consideration of the dating of Pictish symbols (1984). Thomas $(1963,62)$ did, however comment on the small size of the stones, suggesting that Dunnicaer No.2 and No.3 were art mobilier rather than Class I standing stones of a more conventional type. In the 1980s Ralston and Inglis $(1984,47)$ returned to the dating issue, suggesting that the stones were early in the Pictish carved stone tradition, perhaps as early as the fifth century $\mathrm{AD}$, but they acknowledged that other scholars suggested a much later, seventh century date for the carving of these monuments.

Alcock and Alcock (1992, 279-280), following Allen and Anderson, regarded No.3 and No.4 as early stages in the development of two iconic Pictish symbols - the crescent and v-rod and the double-disc symbols respectively. They also identified the Dunnicaer stones as plaques rather than the more common stelae, suitable for displaying within a wall-face rather than being part of standing stone monuments. In a later article, Alcock (1996, 2-4) again suggested the Dunnicaer symbols were early in the sequence, so-called ' $U r$-symbols', and that they might date to the sixth century. Henderson and Henderson $(2004,171)$ in their magnum opus on Pictish art also suggested the Dunnicaer stones were amongst the earliest - placing carvings in caves and other 'remote locations' at the start of the symbol tradition. They suggested that the carving of such symbols began in the pagan period, though they did not provide a chronological date for the beginning of the tradition. 
There have, however, been opposing views with some suggesting the Dunnicaer stones were not necessarily early. Katherine Forsyth $(1997,93)$ argued that they and similar designs found in caves at East Wemyss, Fife and Covesea, Moray, might merely be informal, 'cursive' versions of the standard symbols; and Mack $(2007,200)$ has contended that the Dunnicaer stones were simply poor copies of standard symbols. However, Alcock had earlier dismissed the idea that the cave or Dunnicaer symbols were informal, late or poor versions of more formal symbols $(1996,4)$, highlighting the likely development of relatively simple to more complex designs, with the Dunnicaer examples that dispaly little in the way of internal decoration therefore likely to be early in the Class 1 sequence. This interpretation has been followed and elaborated on by Noble, Goldberg and Hamilton $(2018,1342)$ in a recent reconsideration of the chronology of the Pictish symbol tradition.

\section{Early interpretations of Dunnicaer}

In terms of interpreting the Dunnicaer stack as an archaeological site, Thomson believed that the stack from which the stones had been found had once been joined to the mainland $(1859,71)$ (See below). Citing the place-name, he believed that it had been defended, referencing the Pictish fort at Burghead, Moray, as a parallel. Stuart $(1867,9)$ too interpreted Dunnicaer as a promontory fort, but suggested that the site may have also been used as a hermitage by a Christian missionary at a later period. Allen and Anderson (1903, 200-201) recorded the stones from 'Dinnacair Rock' and interpreted the site as a settlement. Watt $(1914,53)$ followed Stuart in interpreting Dunnicaer as a fort that was also used as a retreat by a hermit. Likewise, Simpson $(1937,3)$ speculated that there may have been a missionary church of Ninian on the cliff-edged promontory of Dunnottar rock and suggested that Dunnicaer may have been a place of retreat for the clergy of the church with the salmon carving on Dunnicaer No. 2 emblematic of Christ. 
Charles Thomas $(1963,36)$ only mentioned Dunnicaer in passing, but interpreted the site as a 'ruined fort'. In 1983 Dunnicaer No.5 was gifted by the then owners of Beannachar House to the University of Aberdeen and put on display in a 1984 exhibition: Foul Hordes: the Picts in the North-East and their background. In the exhibition catalogue, Ralston and Inglis (1984, 47-8) interpreted Dunnicaer simply as an 'enclosure'.

Alcock and Alcock $(1992,281)$, who excavated at nearby Dunnottar, the site referenced in seventh-century Irish annalistic accounts, did not believe that erosion could have been a big factor in the appearance of the stack so they argued that the location was likely to have been little different in the Pictish period to what it looked like in the late twentieth century. They suggested that the stones had been set up as plaques within the inner face of the wall identified in the nineteenth century on the edge of the stack and that the stack was chosen for its striking natural properties and inaccessibility as the location of a pagan cult-focus. They argued that Dunnicaer stood next to a possible fort on the adjacent promontory of Bowduns, a headland of almost 5 ha in extent. This led them to doubt that the Dunnottar promontory occupied by the later castle was the one referred to in Irish seventh-century annals as the site of Dun Foither and that Bowduns was that location. While the Annals of Ulster (AU) record Dunnottar as being under siege twice in the late seventh century, Alcock and Alcock $(1992,282)$ suggested that the place-name may have shifted in the medieval period and that Dunnicaer and neighbouring Bowduns were the sites referred to in the annals. However, a 5 ha fort would be relatively unusual for this period (Dunnottar Castle occupies a headland of c. 1 ha) and the 'strong traces of a ditch, and less clear signs of an internal rampart' interpreted by Alcock and Alcock $(1992,281)$ as enclosing Bowduns had earlier been dismissed by Ordnance Survey surveyors as a cultivation enclosure (NRHE 
No. 37010). Certainly, the putative enclosing bank follows the bottom of the sloping ravine that leads down to the sea, making it an unlikely defensive element (and see discussion in Ralston 2004, 42). Geophysical survey of the headland by the University of Aberdeen failed to show any definite archaeological features there. Ralston (2004, 38-39) returned to the interpretation of Dunnicaer as a probable fort, though noted the extent of erosion and the grass cover made identification difficult. Mack (2007, 160161) also interpreted Dunnicaer as a fort, though he suggested some of the stones could have been re-used grave-markers.

\section{The place-name}

Simon Taylor

Both the Dunnicaer and Dunnottar place-names contain as the generic the Gaelic dùn or its Pictish cognate *dun, meaning '(fortified) hill, hill-fort'. To take the better-known Dunnottar first, we are fortunate in having two exceptionally early references to a siege of a stronghold called Dun Fo(i)ther (AU under the year 681 and 694, equivalent to A.D. 680 and 693 respectively), which is generally accepted as being Dunnottar (see Anderson 1980, 142-3) (Table 2). This helps to identify the second element as the word which is later found in Gaelic as foithir or variants of, and which appears chiefly in Scottish place-names as Fetter- (e.g. Fettercairn Kirkcudbrightshire, Fetteresso Kirkcudbrightshire, Fetternear Aberdeenshire, Fetterangus Aberdeenshire), although it is also found with $o$ instead of $e$ in the first syllable (e.g. Fodderty, Ross-shire and Forteviot, Perthshire (Fothiurtabaicht 858 Poppleton MS [Anderson, 1980, 250]). W. J. Watson would interpret it as 'a slope, a terraced declivity' (1926, 509-12). It is, however, more complex than that, as can be seen from the lengthy discussion of this word in (Taylor with Márkus 2012), the conclusion in that publication being that in most of these names, almost all of which are noticeably high-status (royal centres, early 
parishes etc.), we are probably dealing with a Gaelic adaptation of an underlying Pictish *uotir or the like, meaning 'territory, district', perhaps some kind of administrative unit (see also Taylor 2000, 205, 2008, 277-8). Dunnottar would certainly fit into this pattern of early high-status names, and can be rendered something like 'the stronghold or fortified hill of a territory', the territory being some (otherwise unspecified) administrative or tribal division of Pictland. As these earliest references are dated to well within the Pictish period, we must originally be dealing with a Pictish name. However, the second element, as it stands, is Gaelic, and so we can assume it is a Pictish word which has been Gaelicised, in much the same way that the AD 747 AU entry referring to Kilrymont (St Andrews), Cinrigh Monai is almost certainly an early Gaelicisation of a Pictish name whose first element was Pictish *pen (for details, see Taylor and Márkus 2009: Kilrymonth). This Gaelicisation found in forms of Dunnottar is not surprising given that the annals at this time were being kept at Iona. The loss of the initial $f$ in the second element is due to lenition. It is found also in Kinneddar (Moray and Fife).

[Table 2 near here]

Dunnicaer has unfortunately no earlier recorded place-name form than the 1860 s (Table 2). While the generic (first) element is clear enough, Gaelic dùn or its Pictish cognate (see above), any speculation as to the etymology of the specific (second) element name must be extremely tentative. It is, however, striking how closely the name resembles Dunnikier (Kirkcaldy, Fife), as well as Dunicher Law (Kilconquhar, Fife). ${ }^{1}$

\footnotetext{
${ }^{1}$ For details of these names, see Taylor and Márkus 2006,s.n. and Taylor and Márkus 2009,s.n., respectively. Note that all the place-name data in the Fife volumes is now online on http://fife-placenames.glasgow.ac.uk
} 
These probably consist of Gaelic dùn '(fortified) hill, hill-fort' + the Gaelic definite article + Old (Scottish) Gaelic * cair, a word which is likely to have been borrowed into Gaelic from Pictish and was used to form place-names in medieval Scotland (see Taylor 2011, 77, 100-1; see also Taylor and Márkus 2012, Elements Glossary s.v.). As in the case of dùn, *cair, too, refers to a fort of some kind, often to a place where there are visible Roman remains. In the name Dunnikier (Duniker $1206 \times 1213$ Dunf. Reg. no. $155)$, the * cair almost certainly refers to the eponymous fort of Kirkcaldy itself, the first element also being * cair (either Gaelic or Pictish). So Dunnikier can be interpreted as 'the (fortified) hill of the fort (*cair)'. While it is not known what the *cair of Kirkcaldy actually was, the dùn must refer to a fortification on the escarpment immediately east of Kirkcaldy harbour, or simply to the escarpment itself. If Dunnicaer does indeed share the same elements as Dunnikeir (and Dunicher), then it can be interpreted as something like a (fortified) hill (dùn), or in this case better 'a fortified promontory', which at the time of coining or through later association may have been associated with another nearby fort, $(*$ cair $)$.

\section{Archaeological Description \& Excavation}

Since the nineteenth century only a handful of people are known to have accessed the stack at Dunnicaer. The stack is cut off at high tide and has sheer cliff faces around most sides preventing easy access. In 1965, Ordnance Survey teams visited and recorded the grass-covered remains of a small sub-circular structure at the north-east end (NRHE No. 37001). Ian Ralston and John Gordon climbed to the summit in 1977, but recorded that there were no obvious features on top (Ralston 1977, 19). Stratford Halliday of RCAHMS visited in 1982 and noted the top of the stack was covered in loose tussocky turf and a few loose stones around the edge of the stack, but recorded no visible structures (RCAHMS 1982, 27). 
[Figure 3 near here]

In 2015 Dunnicaer was targeted for excavation by the University of Aberdeen Northern Picts project. The key aim of the 2015 season was to evaluate the archaeology of the sea stack and the findspot of the five Pictish symbol stones found in the nineteenth century. The first season incorporated a five-day evaluation that took place between $13^{\text {th }}-17^{\text {th }}$ April 2015. The objectives of the evaluation were to define, characterize, and obtain a chronology for, any archaeological deposits evident on the sea stack and to try to understand the context of the stones recovered in the nineteenth century. Two further seasons were conducted on $11^{\text {th }}-22^{\text {nd }}$ April 2016 and $5^{\text {th }}-16^{\text {th }}$ June 2017 , with the aim to further characterize elements of the enclosing rampart and a series of internal buildings and structural features first revealed in 2015 (See Figure 3 for trench plan).

Access to the stack was difficult but possible during low tide. The team approached by walking carefully out around the base of the stack, up a grassy ramp and then undertook a short climb up the south edge. Duncan Paterson, a professional climber from North-East Mountaineering, was on site to ensure safe investigation with rope supports installed to aid with ascending, descending and safe working on top of the stack. The access route involved climbing up a loose and fragmented conglomerate forming a low cliff face that was prone to erosion. A temporary ladder access was installed in 2016 and 2017 to prevent further erosion of the access route.

During all three seasons of excavation all contexts were recorded in plan and section, and where appropriate by measured drawing, digital photography and written description. In 2017 a computer-based recording system using a Microsoft Surface Pro tablet was employed. The trench locations and significant features within these were recorded in three dimensions using a differential GPS. Artefacts were recorded by context and in three dimensions if they were determined to be in situ. Bulk soil samples 
were taken from undisturbed archaeological contexts for further analysis and the recovery of dating evidence.

The site

[Figure 4 near here]

As it survives today the sea stack at Dunnicaer rises to a height of $21 \mathrm{~m}$ and on top is up to $54 \mathrm{~m}$ long (north-east/south-west) and $20 \mathrm{~m}$ wide (north-west/south-east) (Figures 1, 3 and 4). The stack is roughly tadpole shaped with a long tail on the south-west side stretching towards land. The largest part of the stack, identified as the upper terrace, encompasses a flat area measuring a maximum of $14 \mathrm{~m}$ north-west/south-east by $24 \mathrm{~m}$ north-east/ south-west, but the most usable area is only around $14 \mathrm{~m}$ by $16 \mathrm{~m}$. Below this upper terrace is a much smaller lower terrace, which survives to a maximum of $8 \mathrm{~m}$ by $8 \mathrm{~m}$ (Figures 3 and 4). The stack is made largely of conglomerate rock with sandstone veins and its top is covered in short tussocky turf. During the 2015 season the top of the stack was recorded by both measured/sketch survey and dGPS. The survey identified traces of a possible bank on the southern edge of the upper terrace and traces of stonework at the edge of the stack under the turf in the same area. No stonework was evident on the northern side - here erosion of the stack appears to have occurred relatively recently. Extensive slumping of soil and stone from the upper terrace was evident covering a significant proportion of the lower terrace.

\section{Excavation results}

The 2015 excavation involved small trenches and test pits to assess the site for in situ deposits. The 2015 trenching quickly identified the denuded remains of a rampart on the southern side of the stack and a hearth on the lower terrace. The 2016 season focused on recording in detail the deposits on the lower terrace and in the centre of the upper 
terrace. The 2017 season uncovered a series of structures and hearths that survived on the upper terrace. The results below are reported by area rather than by season.

The south-east rampart

[Figure 5 near here]

[Table 3 near here]

An enclosing rampart on the south side of the upper terrace was first identified through survey and excavation in 2015. Trench 2 (TT2) in 2015 was located where a number of stones were observed sticking out of an eroding section above the cliff face (Figures 3 and 5). In this same spot, small pieces of charcoal were also observed. These remains were thought to be part of the denuded remains of the low stone wall surrounding the stack that was identified in the nineteenth century. Under a thick root mat and an organic rich topsoil, three narrow horizontal slots were identified cut into the natural subsoil. Two of these [216] and [217] were substantial features; the third [218] was very shallow. The length of slot [217] as exposed measured around $2 \mathrm{~m}$ and terminated adjacent to a shallow pit [213] that pre-dated the rampart of which the slots were a component. Slot [217] was orientated north-west/south-east and measured up to $0.4 \mathrm{~m}$ wide and $0.17 \mathrm{~m}$ deep. Its sides were near vertical and its flat bottom was cut into the natural. The fill was a dark grey highly compacted silty clay with significant quantities of charcoal and stone packing. Two charcoal samples from this fill produced dates of

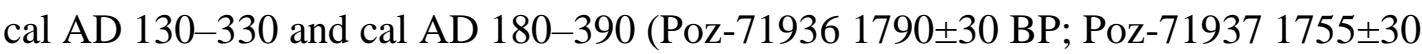
BP; 95\% probability) (See Table 3 for all radiocarbon dates). A large sub-rectangular block of stone (206) lay at the termination of the slot at its inner end along with a small number of additional stones that lay perpendicular to the slots (Figure 5). The stonework here is likely to have been part of the inner face of the rampart with slots [217], [216] and [218] being foundation trenches for transverse timbers, laid as part of timber-lacing or timber-framing for a stone-faced rampart. Small postholes such as 
[208], [210] and [226], located within or below what must have been the rampart core, suggested upright as well as horizontal timbers formed part of the superstructure, though truncation was such here that there was no definite stratigraphic links surviving to definitively show this to be the case. The postholes were around $0.18 \mathrm{~m}-0.20 \mathrm{~m}$ in diameter and $0.15 \mathrm{~m}$ depth, with charcoal-rich fills. Overlying the postholes was a charcoal-rich layer of dark grey silty clay, around $0.05 \mathrm{~m}$ thick. This layer extended from the two postholes towards slot [218]. The spread may represent the burnt/rotten remains of a transverse timber that lay perpendicular to the beam in slot [217].

The second slot [216] was located $1 \mathrm{~m}$ to the south-west of [217] (Figure 5). Only a $1 \mathrm{~m}$ segment of this slot was revealed within the trench, but like [217] the slot extended to the current southern (eroded) edge of the upper terrace. It was on the same orientation and measured up to $0.4 \mathrm{~m}$ wide and $0.25 \mathrm{~m}$ deep, and had very obvious stone packing on its western edge. The fill of the slot consisted of dark grey highly compacted silty clay with a large amount of charcoal. Stone packing on the south-west was set within a compact deposit of re-deposited natural gravel and clay, probable vestiges of wall core fill. A third possible slot [218] was evident $1 \mathrm{~m}$ east of [217]. This was a much more truncated and difficult to define feature, but was evident for around $1 \mathrm{~m}$ extending from the terrace edge. The cut [218] measured about $0.12 \mathrm{~m}$ across with an average depth of $0.1 \mathrm{~m}$. The fill (211) consisted of dark grey compact sand with significant amounts of charcoal mixed in with a few stones.

[Figure 6 near here]

Overall Trench 2 in 2015 revealed a series of shallow foundation slots for timbers that ran perpendicularly to the upper terrace edge; and thus transversely across the rampart. Postholes found next to these slots are taken to represent probable vertical 
timber elements which were also part of the rampart construction; though given the truncation it cannot be ruled out that these shallow cannot represent an earlier phase of enclosure. The very denuded remains of an inner stone wall face were represented by scattered stonework that lay at the end of the slot features; the outer wall face - of uncertain character - is assumed to have been lost through erosion.

In 2016, Trench 1800 was placed to the west of Trench TT2 (Figure 3). Again, stone slabs could be seen here projecting from under the turf at the southern edge of the sea stack. These were again identified as possible vestiges of the low stone wall identified in the nineteenth century as surrounding the top of the stack (Stuart 1856, 14). On excavation it was shown that in this part of the terrace edge the stones were not set directly on the natural, but were placed within a cut in the subsoil and were part of a revetment for the terrace edge and perhaps a foundation for the southern terrace edge rampart in an area where the natural topography sloped downwards from the upper terrace summit. Two courses of stonework survived within a cut around $0.3 \mathrm{~m}$ in depth. Charcoal from the foundation was dated to cal AD 130-340 (Poz-84480 1775 $\pm 30 \mathrm{BP}$; 95\% probability). The stonework consisted of large flat quarried blocks of sandstone, beach-gathered boulders and fragments of conglomerate. The cut in which these stones was set extended to around $1.4 \mathrm{~m}$ wide extending from the current stack edge and was $0.3 \mathrm{~m}$ deep (Figure 6). Fewer stones were found on the northern side of the cut. A clayey silt matrix (including the charcoal mentioned above and used to obtain a date) surrounded the stones. This stone revetment was evident in other eroding sections along the southern edge of the stack. The southern edge of the site had clearly been built up and the fragments of stone revetment/facing and the foundation slots within TT2 are strong evidence for an enclosing wall having been present on the southern side of the stack. 
Topographically it is likely that as is the case today access in the nineteenth century was easiest from the southern side of the Dunnicaer stack. It therefore seems most likely that it was onto the rocky beach on this side that the Stonehaven youths, led by Mr Barr, threw the carved stones in the 1830s. It is on this side that the water is shallow enough to search for objects at low tide, whereas the water becomes significantly deeper northwards. All in all, the traces of a rampart identified on the south side of the stack present the most likely candidate for the low stone wall found by the youths in the 1830s and from which the Pictish sculptured stones were recovered and thrown into the sea. Little now remains of this wall after it and other parts of the stack were quarried for building stone during the nineteenth century (and probably earlier).

\section{Northern side of the upper terrace}

Trench 4 (TT4) was excavated in 2015 to investigate the possibility of a surviving rampart or wall on the north side of the stack (Figure 3). Here erosion of relatively recent date on the side of the stack is very evident, with a sheer bare rock face extending down to the sea. On the upper terrace at the north-westernmost edge a small mound of earth and stone was evident and was targeted for investigation (prior to recognition that the stack is likely to have been much larger than at present). Large quarried blocks of stone were indeed located under the turf. These measured up to $0.6 \mathrm{~m}$ by $0.25 \mathrm{~m}$ and included roughly rectangular blocks of good quality sandstone with fresh, split surfaces obviously brought from a quarry or outcrop. However, none of this stonework was in situ and below these stone blocks was a silty clay deposit up to $0.2 \mathrm{~m}$ thick which in turn overlay more compact charcoal-rich deposits. Within these latter deposits large pieces of charred wood and abundant charcoal were identified (408). Some of this material was clearly from large timbers and charcoal analysis subsequently showed them to be of larch/spruce type - timber only grown commercially for the last hundred 
years or so in Scotland. Radiocarbon dating confirmed that this material was of recent date (Poz-71940 145 \pm 30 BP; cal AD 1660-1950 cal AD, 95\% probability). Hence it is likely that the mound of stone in this area was a result of the quarrying of the stack for building material in the $19^{\text {th }}$ or $20^{\text {th }}$ centuries, perhaps being a dump of stone created before its intended removal from the stack. Below the $19^{\text {th }}$ century disturbance subsoil was quickly reached. Below the nineteenth century disturbance layer, subsoil was quickly reached. Two small postholes cut into the subsoil were uncovered in the centre of the trench - [409] and [410]. These were not excavated and, given the disturbance in this area, could have been modern features.

Upper terrace edge on the east

[Figure 7 near here]

Trench 1 (TT1) in 2015 was placed at the top of the slope down to the lower terrace where there was a noticeable lip along the upper terrace edge (Figures 3 and 7). There is a drop here of around $1.5 \mathrm{~m}$ from the top of the upper terrace to the base of the lower terrace. At the northern edge of the sea stack, stones were evident on the eastern edge of the upper terrace. The trench was thus laid out adjacent to these stones to investigate the character of surviving deposits at the upper terrace edge and to investigate the possible presence of a rampart or wall dividing the upper and lower terraces.

The excavation here showed that the upper edge had been cut back to create a distinct divide between the two terraces - a near vertical edge to the upper terrace platform was evident when TT1 was cleaned back. Within the trench itself there was no evidence of a bank or stone revetment apart from two stones on the northern side of the trench.

Directly under the topsoil, thin, intermittent, occupation layers lying on the subsoil were identified. At the southern edge of the trench a double posthole or the end of a horizontal slot was found $[104,105]$. This slot contained two vertical post-pipes - the 
larger was $0.35 \mathrm{~m}$ in diameter and $0.17 \mathrm{~m}$ deep, the other $0.25 \mathrm{~m}$ by $0.12 \mathrm{~m}$. Both contained a mid-brown silty clay with significant levels of charcoal. This feature continued into the southern section of the trench. It may have been part of a more substantial fence line or post setting marking the terrace edge.

Buildings on the upper terrace - east

[Figure 8 near here]

The most obvious features evident on the upper terrace identified in 2016 and 2017 were two hearths and associated floor layer deposits located just to the north of the rampart on the south. Hearths [003] and [004] (Figures 8 and 9) were found adjacent to each other in a slight hollow on the summit of the upper terrace. Hearth [003], the earlier of the two, was composed of an incomplete sub-rectangular setting of upright kerbstones surrounding some flat paving stones. It measured approximately $0.9 \mathrm{~m}$ by $0.85 \mathrm{~m}$. The internal hearth slabs were uneven and very friable, with several kerbstones missing or slumped, indicating that this hearth had been more heavily used than hearth [004] located immediately adjacent. A radiocarbon date from hearth [003] confirmed its relative age, suggesting it was indeed from an earlier phase of use than Hearth [004] (Poz-84479 1730 \pm 30 BP; cal AD 240-390, 95\% probability). Adjacent to Hearth [003], and stratified beneath Hearth [004] were a series of stake holes and two more substantial postholes [116] and [118], (Plate 8). These could indicate minor structures such as stands or supports for a spit associated with the use of the earlier hearth. Hearth [004] reused some of the kerbstones from Hearth [003] (Figures 8 and 9). It was situated immediately to the south of Hearth [003] and was sub-rectangular measuring $1.05 \mathrm{~m}$ by $0.9 \mathrm{~m}$ with upright kerbstones and flat internal slabs that displayed evidence of use with minor fire cracking on the surface of some of the stones. A sample of 
charcoal from Hearth [004] produced a date of 250-420 cal AD (Poz-84478 1690 \pm 30 BP; 95\% probability).

[Figure 9 near here]

Surrounding Hearths [003] and [004] were dark charcoal-rich floor layers or occupation horizons (007) and (008) (Figures 8, 9 and 10). The floor layers covered an area of around $6 \mathrm{~m}$ north-west/south-east by up to $5 \mathrm{~m}$ north-east/south-west. These layers were largely contained within a slight hollow on the upper terrace and were truncated around their margins; therefore it is uncertain whether they represent the full extent of the original building(s) that had contained them/they were associated with. It is also clear from the plan (Fig. 9) that there was a palimpsest of features here. These floor layers were composed of a dark brown clayey silt with abundant charcoal and calcined bone. They were up to $0.1 \mathrm{~m}$ thick and abutted the kerbstones of Hearths [003] and [004]. A spindle whorl and a granite rotary quern fragment were found in association with these floor layers, along with a sherd of Samian and fragments of Roman glass.

[Figure 10 near here]

At the base of these floor layers another two possible hearths were identified [016] and a further example identified by a group of flags to the south-east [150]. These may be from earlier iterations of buildings set on the same general footing as that associated with Hearths [003] and [004]. Under the south-eastern extent of the later occupation horizon (008) was (020), another earlier feature - a dark black clayey silt spread (around $1 \mathrm{~m}$ by $0.3 \mathrm{~m}$ in extent) with frequent charcoal and fragments of daub. This context (020) produced one of the earliest radiocarbon dates: 70-230 cal AD (Poz98951; $1875 \pm 30 \mathrm{BP} ; 95 \%$ probability). 
Across the upper terrace a series of small to medium sized pits/postholes was identified cut into the natural, particularly in the centre and eastern parts of the trenches on the upper terrace summit (Figure 8). These pits/postholes were of varying sizes, but none was particularly substantial, averaging around $0.2 \mathrm{~m}-0.3 \mathrm{~m}$ in diameter and up to $0.2 \mathrm{~m}$ deep, with the majority showing evidence for having held posts in the form of packing stones., A noticeable concentration of postholes was identified in and around the area of Hearths [003] and [004] and their associated floor layers (Figure 8). As so many small postholes were present it was hard to disentangle which features were associated with one another and it is likely that these represent the building and rebuilding of a series of structures in this area. This pattern of recurrent use is also suggested by the hearths found across the upper and lower terraces - with hearths superimposed on top of, or immediately adjacent to, one another suggesting that structures were built, repaired and replaced while retaining similar groundplans and on the same or similar footprints.

[Figure 11 near here]

While the patterns of postholes were difficult to disentangle, the concentration around hearths [003] and [004] deserves further scrutiny. Many of these were contained within the area covered by the floor layer spreads associated with Hearths [003] and [004] and it may be that some of these were structural features associated with buildings surrounding these hearths [003] and [004]. However, many of these features were only evident once the overlying floor layers (007) and (008) had been removed. It is also the case that hearths [003] and [004] did not lie centrally to the main concentration of these features. The majority of postholes might therefore have been from earlier structure(s) and the general distribution of these suggest that they may have been elements of a rectangular building around $5.5 \mathrm{~m}$ by $4 \mathrm{~m}$, aligned north-east/south-west (Figure 11). 
One of the putative earlier hearths [016], represented by five thin fragmentary firecracked flat stones, was positioned centrally within the concentrated distribution of postholes in this area and may thus have been a central hearth for an early post-framed building here. A scattering of small postholes to the north of floor layers (007) and (008) formed no obvious pattern in plan and could be related to subsidiary structures, such as fences or enclosures placed to the north of the rectangular post-framed structure considered above. Alternatively, they may relate to other buildings, only fragments of which have survived.

Large pits

On the upper terrace were three large pits, [037/1201] [063] and [074] (Figures 8 and 11). Both [063] and [074] were cut by later, smaller postholes. All three pits were cut into natural contained sherds of hand-coiled pottery. Pit [063], was $1.2 \mathrm{~m}$ in diameter and $0.3 \mathrm{~m}$ deep. The fill (1267) comprised a series of dumps, some with significant quantities of charcoal with a distinct concentration of charcoal towards the base of the feature. The base was irregular suggesting the pit itself had been recut. Fragments of pottery were found concentrated around the base and sides of the feature. Pit [1201] was the largest and most complex of these three features (Figure 8). This consisted of a pit $1.1 \mathrm{~m}$ by $1.4 \mathrm{~m}$ in maximum dimensions and $0.6 \mathrm{~m}$ deep. The fills consisted of a series of material with lenses of charcoal evident through the fill. The fills varied from dark brown-black clayey silts to lighter patches of tannish-brown clayey silt. Patches of orangey clayey-silt may suggest deposits of burnt turf within the pit fill. Fragments of hand-coiled pottery were found throughout the pit fill and a burnishing stone was found towards the top of the pit.

Structural features on the upper terrace - west

[Figure 12 near here] 
In the western part of the trench, one of the earliest features identified consisted of a fragmentary cobbled surface (013) (Figure 12), consisting of discrete areas of compacted small rounded beach pebbles c. $0.05 \mathrm{~m}$ in maximum diameter embedded in the subsoil. The fragmentary nature of this surface was likely due to later intense activity on the upper terrace cutting into and disturbing these cobbled layers. Excavation showed that the cobbled surface was cut by a later palisade slot [078] and was also overlain by the wall [015] of a later building (Figure 13).

[Figure 13 near here]

Four hearths were found in the same general area as the cobbled surface. The earliest were hearths [144] and [145] (Figure 12). All that remained of hearth [144] were two flat stones and two kerb stones on a similar alignment, these flat stones lying directly under hearth [082]. It is possible that this early hearth was associated with the cobbled surface (013) and that together these comprise all that remains of an early structure, but the relationship between the hearth and the cobbles was uncertain. As the palisade slot / gate-setting [078] was later than the cobbling, the implication is that if hearth [144] was associated with the cobbling then these were parts of a structure which was built before at least one of the enclosing elements of the promontory. Hearth [145], comprising only of a small number of hearth stones set on edge was also an early feature and appeared to have been truncated by the collapse of the edge of the stack to the north-west and by the construction of hearth [080] on the south-east. This hearth [080] in turn overlay a severely truncated earlier hearth [145] and was composed of kerb stones on its south and west side. The north-western side of hearth [145] (and probably that of [080]) had eroded from the stack, but the approximate extent of the latter feature would have been $0.5 \mathrm{~m}$ wide by a minimum of $1.2 \mathrm{~m}$ long. Hearth [082] overlay palisade slot [078], and therefore post-dated the destruction of what may have 
been just one phase of a landward boundary (see below); as noted above it also overlay Hearth [144]. Hearth [082] was composed of fragmentary remnants of cracked and jumbled flat slabs. This surviving hearth was c. $1 \mathrm{~m}$ by $0.5 \mathrm{~m}$ as it survived and was orientated roughly north-east to south-west. Some upright stones from the south-western kerb remained in situ.

\section{Palisade slot}

The narrow linear cut [078] measured $0.3 \mathrm{~m}$ wide by $0.2 \mathrm{~m}$ deep and was identified towards the western end of the trench (Figure 12). It cut through the cobbled surface (013) and was overlain by hearth [082]. The slot extended from the northern edge of the stack to the southern edge, a length of at least $5 \mathrm{~m}$, and was oriented north-west/southeast. The feature was truncated by erosion on the northern and southern sides. During excavation, fragments of a large charred timber were identified running longitudinally down the centre of the cut. This could have been a collapsed upright, with the charring suggesting destruction by fire. However, it could also be the case that the timber was originally an earthbound sleeper beam into which uprights were morticed. Whichever interpretation is preferred, slot [078] appears to have cut off the eastern part of the stack, presumably acting as a barrier to access from the west. Three small postholes [122], [128] and [126], found around $1 \mathrm{~m}$ to the west of [078] may have held internal supports for the enclosing boundary or even foundations for a wall-walk. A more ephemeral slot [033], that ran parallel to, and a further $1.2 \mathrm{~m}$ in from, palisade slot [078], may have been another associated feature or perhaps part of the footings of a narrow timber wall around $2 \mathrm{~m}$ wide if directly related to slot [078]. At some point feature [078] was dismantled with hearth [082] constructed over its foundations - it may be that at this time the landward boundary (and presumably entrance-way) was moved further west to allow more room for structures within the upper terrace. 


\section{Sub-rectangular building}

[Figure 14 near here]

Overlying all these features in the western area of the upper terrace was a later structure, formed by wall [015] and [011] (Figures 13 and 14) that may have been part of a late settlement phase. The wall was composed of a curving segment of stone surviving to one course high. It was well faced on its inner and outer aides, but used relatively modest, generally rounded glacial, stones in its construction. This building was orientated north-west/south-east. The wall of the structure survived better on the western side and was around $0.5 \mathrm{~m}$ thick and extended at least $3 \mathrm{~m}$ in length, but had been truncated by erosion on the north side of the stack. On the south-east the wall curved round to form the end of the structure, and the projection of its arc extended towards a fragmentary setting of stones [011], which is perhaps all that remained of the north-eastern side wall of the structure. This low stone component appeared to be the footing for a turf wall, for the stones were not well bedded and revetted a loose sandysilt soil matrix (022), which in turn sat on a layer of compact loamy soil (069) - itself perhaps the remnant of an earlier turf wall. A loamy soil matrix (1404) was also found around the surviving stones of the eastern wall; these stones too lay above a deposit of similar material up to $0.1 \mathrm{~m}$ thick - again the likely remnants of an earlier turf wall. Charcoal from context (069) produced a radiocarbon date of cal AD 240-390 (Poz95954; 1735 \pm 30 BP; 95\% probability). Charcoal from a spread contained by wall [015] was dated to cal AD 340-540 (Poz-95952; 1630 30 BP; 95\% probability), suggesting that this building and its occupation was one of the latest phases of activity to be dated. The surviving ground-plan suggests a sub-rectangular building up to $4 \mathrm{~m}$ wide and at least $4.5 \mathrm{~m}$ long, though truncation on the north-west and north-east sides makes reconstruction of its form difficult. Cobbling (013) followed the general outline of the 
sub-rectangular structure suggesting that the building may have been built on the same footing as an earlier structure. Given the lack of surviving walls in association with the hearths found elsewhere on the site it may be that all of the structures on the stack had walls of similar character to that of of [015], but it may be proposed that the majority were dismantled as the buildings were replaced, with only the walls of the later structures surviving in situ.

Structures on the lower terrace

Little survived of the lower terrace in terms of its extent, but targeted excavations revealed two further hearths in the small area that has not been lost to erosion. The lower terrace also showed better preservation with surviving deposits up to $0.4 \mathrm{~m}$ in depth. This is due to a number of factors: one was that slumping of deposits from the upper terrace had partly preserved the features of the lower terrace better; stone quarrying on the upper terrace is also likely to have had an impact on the survival of deposits there; and, surprisingly, the upper terrace was also cultivated in the nineteenth century. Thomson $(1859,71)$ recounts that some years previously an enterprising fisherman had grown crops on the flat summit of the upper terrace, and though this has left no archaeological trace, it must have had a substantial impact on the survival of deposits.

[Figure 15 near here]

On the lower terrace the small $0.75 \mathrm{~m}$ by $1.7 \mathrm{~m}$ evaluation trench dug in 2015 identified a stone-built hearth and this area was extended in 2016 for further investigation (Figures 3 and 15). Significant deposits of slumped material that had fallen from the upper terrace were evident overlying the deposits on the lower terrace. These slumped deposits consisted of a very loose overburden of small stones and organic humic-rich soils. Below these upper layers was an in situ midden layer, up to $0.1 \mathrm{~m}$ 
thick, of organic-rich soil with abundant charcoal and a few small fragments of poorlypreserved animal bone. This lay directly over the remains of the lower terrace consisting of an upper sub-rectangular hearth [1008] set amidst associated floor layers (Figure 15a). To the south-west of the hearth, bedrock was identified sloping upwards only a short distance from the hearth, but on its other sides floor layers were found extending eastwards. On the west side of the hearth a distinct charcoal- or ash-rich deposit was evident - probable ash rake-out from the hearth. Charred animal bone was also recovered from the floor layers next to the hearth and a large cut piece of bone was found in the soil matrix directly above hearth [1008], which survived in excellent condition and was $1 \mathrm{~m}$ long by $0.8 \mathrm{~m}$ wide. The hearth stones were a mixture of split and rounded beach cobbles up to $0.23 \mathrm{~m}$ in maximum width/length.

[Figure 16 near here]

Hearth [1008] lay directly over another hearth [1012] from an earlier phase (Figures $15 \mathrm{~b}$ and 16 ). The stones of the earlier hearth were significantly more firecracked than those that made up the later hearth. This earlier hearth was also significantly larger (at least $2 \mathrm{~m}$ long but a similar width), but was constructed in a similar way with flat central stones and upright stones set into the floor to mark the edge. No clear kerb stones were found on the south side possibly due to reuse of some stones for the later hearth. The extent of fire damage to the stones indicated intensive and perhaps long-lived use of this feature. Next to hearth [1012], on the west side, lay a stone used as a whetstone for sharpening blades (this was left in situ).

[Figure 17 near here]

Like Hearth [003] and [004] on the upper terrace, the lower hearth [1012] here was constructed and survived in a slight hollow in the bedrock/subsoil. The material 
above and around the lower hearth consisted of black charcoal-rich soil (1013), with a similar deposit (1011) extending onto bedrock to the south (Figure 15b). A small sondage was excavated near the southern baulk of the trench to establish the depth of floor layers at this location: almost $0.3 \mathrm{~m}$ of floor layers/levelling survived in this area (Figure 17). These followed the profile of the bedrock that sloped away to the east. Directly on the bedrock lay charcoal-rich layers (1011) and (1013), and above them was context (1009), which consisted of a mid-brown clayey silt with multiple charcoal-rich lenses.

No definite traces of outer walling suitable for a building or postholes were identified in association with the hearths on the lower terrace. However, the area for investigation was severely restricted by space and safety concerns. Hence it is uncertain whether any full building plans may survive on the lower terrace or whether much has been lost to erosion. Certainly, both hearths were so close to the edge of the stack, that it is likely that the superstructure of any associated building, whether it was in the form of postholes or turf/stone walling, has been lost to erosion at least on the seaward side. A harder packed deposit of what appeared to be redeposited natural that sat directly above the bedrock on the eastern edge of the trench could have represented the foundation of a turf wall, but again the possibilities for further investigation were limited. Small finds from the floor layers on the lower terrace included a sandstone disc roughout and a piece of hand-coiled pottery.

\section{The Finds Assemblage}

\section{Hand-made Pottery}

Gemma Cruickshanks

[Figure 18 near here] 
An assemblage of 36 sherds of hand-made pottery from a minimum of ten vessels was recovered from Dunnicaer (Figure 18) (Table 4). Most of the sherds were recovered from a pit while smaller quantities were retrieved from floor layers. Where determinable, the vessels all had everted or slightly inverted rims, flat bases and were most likely vase-shaped in profile. Each sherd was catalogued in accordance with the Prehistoric Ceramics Research Group's recommended methods (PCRG 2011). Sherds were grouped into three fabric groups and assigned vessel numbers based on differences in form, surface treatments and dimensions. Each of the ten 'vessels' represents a minimum of one, but could conceivably include additional vessels sharing similar forms and fabrics. Degree of wear was recorded along with the position and extent of residues and/or soot. The assemblage is summarised here with a catalogue entry for each vessel at the end. A full catalogue detailing each sherd is in the archive.

[Table 4 near here]

\section{Fabric}

Three fabric types were identified:

A: Fine sandy clay with a few small (c. $0.1-1 \mathrm{~mm})$ quartz inclusions (c.5-10\%) (Vessels $1,4,5,7,9$ and 10).

B: Similar to A, but notably finer with fewer, smaller sandy inclusions (Vessels 2, 3 and 8).

C: Similar to A, but with distinct mica inclusions (c.5\%, 0.5-4mm) (Vessel 6).

The fabrics are not particularly distinct as a group but are markedly different from early prehistoric pottery fabrics in the area, which tend to be less sandy and tempered with large rock fragments (McGill 2001, 257). Thin-section analysis of similar fabrics from Covesea Cave and Birnie, both in Moray, (Sahlen 2009, 36, forthcoming) has shown that such fabrics were usually locally sourced and while their inclusions appear 
indistinct, their regularity and even distribution suggests they were deliberately added (Sahlen forthcoming).

Form

Seven vessels have everted rims [V1, 2, 4, 5, 6, 7 and 9] while three were slightly inverted [V3, 8 and 10]. Three basal sherds are present from Vessels 1 and 4/5, illustrating they were flat-based. While no complete profiles survive, the combination of surviving sherds suggest the vessels were vase-shaped with either everted or inverted rims, rounded shoulders and tapering to narrow, flat bases. Vessel 1 is notably more robust than the others, with walls c.10mm thick and a base $15 \mathrm{~mm}$ thick, compared to an average wall thickness of $7 \mathrm{~mm}$ and base thickness of $8.5 \mathrm{~mm}$ for the other vessels. The rim sherds from Vessels 1 and 5 are sizable enough to estimate their original external rim diameter. Both are fairly similar in size, with V1 160mm in diameter and V5 at $140 \mathrm{~mm}$. The rim sherds from the other three vessels are too small for rim estimation to be meaningful.

\section{Technology and manufacture}

Two manufacturing techniques are evident: diagonally-joined straps and the 'tongue and groove' method. The broken section of the base of Vessel 1 clearly shows the angled join between clay straps, while sherds from Vessels 4/5, 9 and 10 display the grooves and 'false rims' associated with tongue and groove construction. Both techniques have a long history of use throughout prehistory up until the establishment of wheel-made pottery during the first millennium AD (Gibson and Woods 1990, 39). The sherds are predominantly oxidised on the exterior with a reduced core, suggesting reasonably consistent firing conditions in the kiln. A few grass impressions are visible in some broken edges as well as surfaces, indicating grass (or straw/ chaff, etc.) was deliberately included within the fabric (rather than wet pots simply having rested on 
grass). None of the vessels display decoration, but their surfaces were in many cases wiped or smoothed prior to firing. Smoothing could be undertaken with a wet hand or cloth, either for aesthetic reasons or to seal any small gaps to improve waterproofing. The smoothing of both the internal and external surfaces suggests it was not simply for aesthetics.

\section{Function}

Vessels 1, 2, 4, 5, 7, 9 and 10 all show sooting on the external surface, suggesting they were used for cooking on or by an open fire. Vessel 1 has thick encrusted, carbonised residues on the interior of the base and fragments on the rim which are likely to be the remains of whatever was being cooked. The vessels' diameters $(140-160 \mathrm{~mm}$, where measurable) are at the smaller end of the spectrum compared to other similar vessels in contemporary north-east Scottish assemblages. For example, the vessels at Tarradale, Highland, have rim diameters between 150-300mm (McGill 2001, 256), and between 100-300mm at Redcastle, Angus (McGill 2005, 77). Two pots from silver denarii hoards at Birnie, Moray, have rim diameters of 160 and 200mm (measured by the author) and the Roman Iron Age vessels at Sculptor's Cave, Covesea are between 110 and 190mm in rim diameter (Cruickshanks and Sheridan forthcoming). The combination of cooking residues and small-medium size suggests the Dunnicaer pots were used for cooking or serving food for relatively small groups of people.

Wear

The degree of wear on each sherd was recorded on a scale of 1 to 4 , with one being freshly broken and 4 being very abraded. This was used to analyse how much the pottery may have moved around since deposition, thus potentially identifying residual sherds from primary deposits. The Dunnicaer sherds show very little abrasion; Vessels 1-3 all have freshly broken edges (level 1) while Vessels 4-6 and 8-10 show 
slight/medium abrasion on the broken edges and are a combination of levels 1 and 2 . Only Vessel 7 shows more marked abrasion (level 3). This suggests most of the assemblage has moved very little since it was deposited.

\section{Distribution}

Most of the sherds (24/36) were recovered from a single pit [1201] on the edge of the house floor layers (Table 4). The sherds from this pit are from seven different vessels $[\mathrm{V} 1,3,4,5,8,9,10]$, indicating this is a deposit of mixed material rather than the remains of a single pot, though the relatively unabraded state of the sherds indicates they had not moved around much since breakage.

\section{Discussion}

Securely-dated Roman Iron Age pottery is scarce in north-east Scotland; the Dunnicaer assemblage, which is stratified in contexts radiocarbon-dated to between the second and fourth centuries $\mathrm{AD}$, is thus of great value. Compared to the Neolithic and Bronze Age, pottery appears to have been much scarcer in the Iron Age and Roman Iron Age in this region. Multi-period settlements such as Grantown Road, Moray (McLaren 2016), Kintore, Aberdeenshire (MacSween 2008), and Culduthel, Inverness (MacSween forthcoming), have each produced sizeable early prehistoric pottery assemblages but far fewer Iron Age sherds, despite there being an abundance of Iron Age archaeology and other artefact types. The lowland brochs, which have periods of occupation contemporary with Dunnicaer, produce very small pottery assemblages. For example, the substantial artefact assemblages from Fairy Knowe broch, Stirlingshire, only produced two sherds of prehistoric pot (Willis 1998, 328) and recent excavations at Castle Craig, Perthshire, produced none (Hunter and Cruickshanks in prep.).

Despite the scarcity of contemporary pottery assemblages, there are small numbers of sites which do provide good parallels for these vessels. For example, two 
pots of similar everted-rim form and fabric to those from Dunnicaer were discovered at Birnie, Moray, containing hoards of late-second century AD Roman denarii (Holmes 2006, 3, fig.2). Examples have also been recovered from Redcastle souterrain, Angus, dating to the first few centuries AD (McGill 2005, 79 illus. 18). Catherine McGill (2001, 257-8) proposed a broad chronological shift from fabrics with large igneous or metamorphic inclusions in the pre-Roman period, to sandy fabrics with little or no inclusions from the Roman Iron Age onwards, which is consistent with the assemblage from Dunnicaer. However, recent reassessment of the artefact assemblage from Sculptor's Cave, Covesea, shows that a few of the flat-rimmed vessels from the Late Bronze Age and Early Iron Age layers are also in this fabric (Cruickshanks and Sheridan forthcoming); the pattern is becoming more complex. So far, the combination of both everted rims and fine fabrics does appear to be confined to the Roman Iron Age onwards in north-east Scotland, but exactly when they began and how long they were manufactured for is a topic requiring more assemblages and further study. In conclusion, the form and fabric of the pottery assemblage from Dunnicaer are consistent with the second to fourth century radiocarbon dates obtained from the site and are a valuable addition to the sparse corpus of contemporary assemblages in north-east Scotland.

\section{Catalogue}

A full catalogue of each sherd is in the archive. Measurements are in $\mathrm{mm}$.

Abbreviations: D diameter, $\mathrm{T}$ thickness, SF small find number, $\mathrm{Tr}$ trench, $\mathrm{C}$ context. Vessel 1

A basal sherd (SF1029), wall sherd (SF18) and two refitting rim sherds (SF28 and 1036) from a chunky, flat-based vessel with short, weakly everted rim. The fabric is oxidised on the exterior but reduced in the interior and core, and both the interior and 
exterior have adhering carbonised residues. There are occasional grass/organic impressions on both faces. No surface treatments are apparent and the sherds show little abrasion. Fabric A. Estimated rim D 160-180; wall T 9; base T 15.

SF18 and 28: Tr.1, C.75, pit [1201]

SF1029: Tr.1001, C.1029, lower terrace occupation

SF1036: Tr.1200, C.1267, pit [1201]

Vessel 2

A single, sharply-everted rim sherd (SF1005) from a fairly fine, thin-walled vessel. Both sides were wiped prior to firing and display patches of soot and burnt residues. The clay is completely oxidised and the sherd shows little abrasion. Fabric B. Wall T 4.5. Tr.1001, C.1009, lower terrace occupation

Vessel 3

A small tapering rim sherd, probably from an inverted rim (SF1032). The exterior is oxidised while the interior is reduced and the interior has sooting present. Both faces were smoothed prior to firing and the sherd has very little abrasion. Fabric B. Wall T 6. Tr.1200, C.1267, pit [1201]

Vessel 4

A single, small everted rim sherd with ridge on inside edge (SF1012). Both faces were smoothed prior to firing and the sherd shows slight abrasion around the broken edges. The fabric is completely oxidised. Fabric A. Wall T 6. Tr.1200, C.1267, pit [1201] Vessel 5

Three rim sherds from an everted-rimmed vessel with walls of medium thickness (SF1034). The clay has occasional grass/organic impressions throughout and both the interior and exterior were smoothed prior to firing. The exterior is oxidised while the 
core and interior are reduced. Very little abrasion. Fabric A. Estimated rim D 140; wall T 7-8. Both sherds from Tr.1200, C.1267, pit [1201]

The following sherds could be from either vessel 4 or 5 (all plain wall sherds unless indicated*): SF15 (Tr.1, Unstratified); SF26 (Tr.1, C.008 floor layer); SF29.3 (Tr.1, C.75, pit [74]); SF1002 (Tr.1200, C.1203, pit [1201]); SF1008 (Tr.1200, C.1200, unstratified); SF1019 (Tr.1200, C.1258 = floor layer C.008); SF1022 (Tr.1200, C.1260 = floor layer C.008; thickening towards base); SF1026, 1028*, 1031, 1033, 1035, 1037* (Tr.1200, C.1267, pit [1201])

Vessel 6

A rim (SF13) and body sherd (SF14) from an everted-rimmed vessel with thick walls. The fabric is differentiated from all the other vessels by the presence of distinct mica inclusions. Varies from entirely oxidised to oxidised with a reduced core. There are occasional fine organic impressions on both faces (hair?) and the surface had been smoothed. Very little abrasion. Fabric C. Wall T 12.

SF13: Tr.1, C.7, floor layer upper terrace

SF14: Tr.1, C.8 floor layer upper terrace

Vessel 7

A refitting rim (SF17) and wall sherd (SF23) from an everted-rimmed vessel with medium-thick walls. Both faces were smoothed and have fine organic (hair?) impressions with sooting on the exterior. Oxidised fabric. These sherds are notably more abraded than others. Fabric A. Wall T 7-8. Both sherds from Tr.1, C.64, pit [063] Vessel 8

A rim sherd (SF24) from a relatively thin-walled vessel with straight or slightly inverted rim. The vessel has sooting on the interior and has been smoothed whilst wet on both 
faces, especially the exterior (creating the appearance of a slip). Oxidised fabric with a reduced core. Very little abrasion. Fabric B. Wall T 5. Tr.1, C.75, pit [1201] Vessel 9

A rim sherd (SF29.1) from an everted-rimmed vessel, very similar to Vessel 5 but with thicker walls. The vessel was smoothed on both surfaces, with coarser striations also suggesting rougher wiping prior to firing. Slight sooting and occasional organic grasslike impressions on the exterior. Oxidised faces with a reduced core. A groove on the broken section indicates the pot was constructed using the tongue and groove method. Fabric A. Wall T 9. Tr.1, C.75, pit [1201].

Vessel 10

One rim sherd (SF27.1) and six wall sherds (SF27.2, 29.2, 30, 31, 32, 33) from a vessel with gently inverted rim and medium-thick walls. The pot had sooting on both sides and a few possible grass/organic impressions, mainly on the exterior. Both sides had been smoothed, with coarser striations suggesting it was also roughly wiped. Several of the wall sherds are 'false rims' created during the tongue and groove construction technique. Very little abrasion. Fabric A. Wall T 8-10. All sherds from T1, C.75, pit [1201]

\section{Roman Pottery}

\section{Colin Wallace}

[Figure 19 near here]

Five sherds of Roman pottery from three vessels were recovered, comprising a samian sherd, a sherd of greyware cooking pot and three sherds of black burnished ware (Figure 19). The sherds have been recorded to the Ceramic Archive level set out in the Study Group for Roman Pottery's Guidelines (Darling 1994) in order to assign a reasonable date to the assemblage, to give an indication of potential and to lend itself to useful 
comparison with other contemporary groups from North Britain. Wares have been linked as far as possible to the published descriptions of the National Roman Fabric Reference Collection (NRFRC) (Tomber and Dore 1998).

\section{Samian}

A small, worn piece of second-century AD Central Gaulish decorated samian bowl, probably Antonine (and probably Form 30) (SF1005, Figure 19) was recovered from an upper floor level (C.008) of a structure dating to the third and fourth centuries AD. This upper bodysherd is now lacking the rim; it starts with a zone of four horizontal grooves and simple round mouldings (or rilling) immediately on top of the ovolo, which is itself immediately above the beading and worn-away (freestyle?) decoration. It is consistent with NRFRC fabric LEZ SA 2 (Tomber and Dore 1998, 32-33); the slip is too good to be East Gaulish. It was part of the upper wall from a form 30, on the evidence of the internal groove that is a feature of that type, and the thinner wall (here, $5 \mathrm{~mm}$ ) in comparison with form 37. It is now a not-quite-rectangular sherd, the slip less worn on the interior than the exterior; greatest dimensions $35 \mathrm{~mm}$ (vertical) and $20 \mathrm{~mm}$ (horizontal), weight $4.1 \mathrm{~g}$.

\section{Coarsewares}

A very burnt Roman greyware cooking-pot rimsherd (SF009) was retrieved from one of the deposits surrounding the hearths (C.007). Now burnt orange-brown, enough survived to show that the original pot had a thickened, out-turned rim and was therefore broadly of later second to third century AD date. Length $36 \mathrm{~mm}$, height $21 \mathrm{~mm}$, thickness $9 \mathrm{~mm}$, weight $11.2 \mathrm{~g}$.

Three non-joining lower bodysherds from the same southern British blackburnished ware 2 (BB2) cooking pot (SF005) were found in another of the deposits around the hearths (C.008). One sherd just preserves the basal angle of the original pot. 
Now all burnt black and heat-damaged, the largest bodysherd might show some incised lattice from the bottom of the original decorated zone, but the outer surface is in poor condition. BB2 came largely from Thameside Essex and Kent (NRFRC fabrics COL BB 2, MUC BB2, CLI BB 2 and COO BB 2; Tomber and Dore 1998, 131, 135, 165, 166) and was exported north from the Antonine period throughout the third century AD, becoming the dominant coarseware (Bidwell 1994, 221, 226-8; Bidwell and Croom $2002,153)$

\section{Discussion}

Sherds from one samian bowl and two coarse ware cooking pots were recovered. In terms of original manufacture, the Roman pottery is of second/third centuries AD date. In terms of use-life, the context of at least one of the finds (the BB2, SF005) is arguably third-century and thus likely short-lived, while the samian fragment could easily have been deposited late in the overall second to fourth century AD date-range for the use of the part of the site from which the pottery was found. As such, the Dunnicaer assemblage encompasses different vessels with more than one style of object-biography. The samian (SF1005) can be considered one of the smallest pieces of such a vessel that one could fragment down to and still be a recognisable 'Roman' /symbolic object. Not curated, by contrast, the original greyware (SF009) and BB2 vessels (SF005) from around the hearths had clearly been in use as 'working pots', in much the same manner as the locally-made-pottery. The samian bowl links Dunnicaer to other non-military sites of the second/third centuries in the north of Roman Britain which received a lesser variety of Roman wares than those of first century date or further south. The form 30 samian bowl was not the commonest decorated bowl type in the export repertoire of the Central Gaulish samian industry in the second half of the second century; that was the deeper decorated bowl form 37, well-represented on Scottish sites generally (both 
Roman military and non-military), alongside the plain samian bowl form 31 . The curation of samian is a phenomenon that occurs across the Insular barbarian world in the Iron Age and early medieval periods. The question of the fragmentation and deposition of samian in north-east Scotland has been recently discussed (Wallace 2019), where something of a samian-specific fragmentation continuum can be observed, from relatively large pieces (e.g. Tillydrone, Aberdeenshire, unpublished; examined by the author) to very small pieces, such as those at Sculptor's Cave, Covesea (Wallace forthcoming a). Sherds from Dunnicaer and Deskford sit towards the small end of this spectrum. Other samian finds from north-east Scotland include an unprovenanced find of decorated samian, possibly from the Rhynie area, Aberdeenshire (Kilbride-Jones H E 1935, 454), as well as Central Gaulish sherds from Brackla, Nairn (Pelling 1990, 18), Birnie, Moray (Wallace forthcoming b) and Clarkly Hill, Moray (unpublished, examined by the author).

Roman coarseware sherds are also known from various sites across north-east Scotland, for example, from Kintore, Aberdeenshire (Wallace 2008, 189-90), Birnie (Wallace forthcoming b) and Raigmore, Inverness (Simpson 1996, 65 and 74), though such sherds are likely underrepresented as they are less recognisable than samian. It remains difficult to choose between an argument that the original pottery vessels arrived in the region separately, in the second half of the second and first half of the third centuries respectively, or one that suggests a combined, third-century, arrival. The Dunnicaer sequence provides good evidence for the biographies of the samian and the BB2 at the ends of their lives, but the earlier periods of their lives are shadowy. We know, broadly, how much modification the samian fragment had undergone en-route from a complete bowl, but nothing of where or when that happened, and while BB2 
typology can be problematic, the surviving parts of the Dunnicaer cooking-pot preserve no clues at all as to its typology.

Dunnicaer also reminds us again that the inhabitants of north-east Scotland were not so different from their contemporaries. Just as recent excavations at Rhynie have shown the Picts to have participated in similar 'post-imperial' networks bringing pottery and glass vessels from the Mediterranean world to the Britons and the Gaels of Ireland and western Scotland (Campbell 2007; Noble et al. 2019), so too Dunnicaer (and Covesea; Wallace forthcoming a) indicates their predecessors were collectors and reworkers of earlier Roman pottery.

\section{Stone Objects}

Gemma Cruickshanks

[Figure 20 near here]

Six stone artefacts were recovered; part of a rotary quern (SF12), a spindle whorl (SF002), a probable spindle whorl roughout (SF1001), two metalworking burnishers (SF1001.2 and 1006) and a possible polisher (SF1007) (Figures 20 and 21). Though small, the stone assemblage provides evidence of a range of activities taking place, from everyday tasks such as grinding grain and spinning yarn to the more specialist craft of sheet-metalworking.

\section{Discussion}

Around a quarter of a rotary quern upper stone (SF12, Figure 20) was recovered from charcoal rich layers to the west of the hearth (C.007). Querns were vital household objects which are likely to have been symbolically linked to themes such as the agricultural cycle and fertility (Peacock 2013, 174-5). They would also have been difficult to break accidentally and their fragmentation (often into quarters or halves) and subsequent deposition on settlement sites seems to have been an everyday form of 
structured deposition that occurred throughout the Iron Age (Heslop 2008, 71). The incorporation of this fragment within the hearth's debris may have marked the end of that hearth or structure's use, for example. The quern was discoidal in form, a type which is typical of north and west Scotland in the Iron Age (McLaren and Hunter 2008, $105)$ and was manufactured from local granite.

[Figure 21 near here]

Spindle whorls were used to spin yarn from animal or plant fibres, an everyday task which would have taken place on almost all settlements (Figure 21). The whorl found here (SF2, Figure 21) is relatively light at $16 \mathrm{~g}$, suggesting it may have been used to spin yarns at the finer end of the spectrum. Its narrow perforation is consistent with others in the Iron Age/Roman Iron Age period (Walton Rogers 2007, 23), and while its slightly off-centre perforation may have hindered it spinning as smoothly as a more balanced example, it would still have been functional. A small sandstone disc roughout (SF1001/ C.1007, Figure 21) is the only evidence of stone artefact production at the site. It is so similar in size to the spindle whorl that it seems likely this was its intended function, but a gaming counter is also a possibility. A small polished pebble (SF1007) is likely to have been used against something soft, such as leather or textiles, and its small size and faint wear-traces suggest it was probably used only briefly for a small, fine task.

Two stone tools with smooth facetted edges (SF1001.2/ C.1203 and SF1006, Figure 21) were probably burnishers used in non-ferrous metalworking; this is particularly valuable as no other evidence of this craft was recovered at Dunnicaer. SF1001.2/ C.1203 is heavily modified with multiple facets on all surfaces from repeatedly rubbing against a smooth, hard surface, most likely sheet metal. SF1006 has seen less extensive use but still displays distinct polished facets along one edge. Non- 
ferrous sheet-working is poorly understood compared to casting evidence, as its recognition often relies on identification of tiny offcuts and cut edges. The occurrence of these burnishers has not been collated, but they are rather atypical finds.

\section{Catalogue}

SF2 Discoidal sandstone spindle whorl with off-centre cylindrical perforation and smooth, slightly facetted outer edge. D 36, T 8.5; D perf 6.5; 16.3g. Tr.1, C.002, silt near sub-rectangular building. (Figure 21)

SF12 Around a quarter of a discoidal granite rotary quern upper stone, broken through the conical perforation. No sign of handle attachment survives. The concave grinding surface is smoothed and polished with circumferential striations in places, especially around the outer edge and near the socket. The upper surface is slightly domed and, along with the outer edge, displays regular peck-marks from shaping. Estimated original D 410mm; c.30\% of circumference survives; max T 75. Tr.1, C.007, floor layer upper terrace.

SF1001/ C.1007 Sandstone disc with roughly flaked edges. Otherwise unworked. Possibly a roughout? D 36-38; T 9. Tr.1001, C.1007, charcoal-rich area next to hearth [1008].

SF1001.2/ C.1203 Flat, quadrilateral fragment of siltstone, entirely modified through use as a burnisher. Both faces and all edges have extensive rubbed facets. The facets are a combination of convex and concave, indicating this tool was used to burnish a range of surface shapes. A small patch of burnt residue or corrosion adheres to one side. Probably a fine metalworking tool. L 41, W 41, T 10. Tr.1200, C.1203, pit [1201]. SF1006 Corner of a flat sandstone fragment with two adjacent edges broken. One of the intact edges has been used as a burnisher on both sides, creating a pointed edge with 
smoothed, polished facets either side. L 42, W 34, T9. Tr.1400, C.1401, near to subrectangular building.

SF1007 Small plano-convex pebble with differential polished area on rounded side. 37 x 34 x 16; polished area 31 x 13. Tr.1400, C.1401, near to sub-rectangular building.

\section{Metalwork}

\section{Gemma Cruickshanks}

One metal artefact was recovered: a lead shot or weight (SF1018). The cylindrical lead object (SF1018) bears resemblance to post-medieval 'capstan bullets', but may also have been a weight of some sort. Most weights tend to be perforated but the waisted profile of this one would have allowed string to have been secured around its middle. Lead is very rarely found in pre-Roman Iron Age Scotland, and lead artefacts on Roman Iron Age sites can be seen as further evidence of Roman-native contact (Hunter 1998, 355). If it is a bullet, its nature as a projectile explains its presence in an earlier context.

\section{Catalogue}

SF1018 Small lead cylinder with rounded ends. Slightly waisted. L 20, D 11. 18g.

C. 1258 = floor layers C.008.

\section{Ironworking debris and other vitrified material}

\section{Gemma Cruickshanks}

Three fragments of cinder (SF1010) weighing 1g were recovered from the lower fill of a large pit (C.1203). They are light, porous, black fragments and formed through the partial burning of fuel such as charcoal. Such material can form during a wide range of high-temperature processes from normal domestic hearths to metalworking activity. Two fragments of iron-rich vitrified material (SF1030 and SF1090/C.1009) and a bloom scrap (SF19) may be evidence of blacksmithing. SF1030 and SF1090/C.1009 lack the usual flowed or bubbled texture of iron slag but are not magnetic or distinctly-shaped 
enough to be fragments of iron. They could therefore be from an intermediary stage, created by an accumulation of iron fragments during small-scale blacksmithing, e.g. minor repairs rather than artefact creation. One of the possible iron slag fragments (SF1090/C.1009) was recovered from a floor layer associated with the upper hearth in Trench 1001 (C.1009), implying this may have been the blacksmithing location. The other fragment (SF1030) was within the fill of a large pit (C.1272) in Trench 1200, suggesting the debris was the result of more than one episode, or moved around somewhat.

\section{Catalogue}

SF19 Small fragment of porous, magnetic iron-rich material. Probably a bloom scrap. $23 \times 20 \times 13 ; 7.1$ g. C.53, pit [52]

SF1010 Three fragments of light, porous black slag (two refit), most likely formed from vitrified fuel. 1g. C.1203, pit [1201]

SF1030 Very corroded, part-formed iron fragment. Most likely blacksmithing debris. 3g. Tr.1200, C.1267, pit [1201]

SF? (C.1009) Very corroded, part-formed iron fragment. Most likely blacksmithing debris. 3g. Tr.1001, C.1009, lower terrace occupation

\section{Fired Clay}

\section{Gemma Cruickshanks}

Around 70 fragments of fired clay were recovered weighing a little less than $800 \mathrm{~g}$ (SF020, 1003, 1004, 1013, 1021). Most were from the floor layers on the upper terrace and display a range of shaped surfaces, providing clues as to how the clay had been used. Several fragments have long, cylindrical impressions between 10 and 16mm wide which were probably wooden withies in a wattle wall or screen. Smaller rounded, concave impressions were probably created by fingertips pressing the clay in between 
the withies. These fragments were mostly found in floor layers (007/008), suggesting there were wattle and daub components of the structures at Dunnicaer, either as an outer wall or internal partitions/screens. The clay is a fine silty fabric with occasional (5\%) inclusions of small stones (c.2mm max) and is likely to have been locally sourced.

\section{Catalogue}

SF020 Twenty-three fragments of reddish-orange fired clay. Two fragments have smoothed, concave faces on one side, suggesting this was daub. Largest fragment 29 x 2 x 21; total weight 64.2g. Tr.1, C.007/8, floor layers.

SF1003 Fifteen fragments of reddish-orange fired clay. Three fragments have slightly concave smoothed faces on one side, indicating the clay had been pressed against something rounded. The fragments are generally very abraded and fragmentary. Largest fragment: 41 x 28 x 13mm; 45g. Tr.1200, C.1203, pit [1201]

SF1004 Around 30 fragments of reddish-orange fired clay. Most of these fragments have shaped faces. Some have long concave facets, suggesting they were pressed against long, rod-like objects, most likely wooden withies, i.e. in wattle and daub. Other pieces had small, rounded concave surfaces, possibly finger-tip impressions from pressing the clay in. Largest piece 43 x 32 x 24mm; thickness of withies $10-16 \mathrm{~mm}$; 223g. Tr.1200, C.008, floor layers.

SF1013 Single fragment of orangey-red fired clay with one flattened, slightly concave face from being pressed against something rounded. 19 x 16 x 13mm; 4g. Tr.1200, C.008, floor layers.

SF1021 Single rounded, weathered fragment of orangey-red fired clay. 17 x 17 x 13mm; 4g. Tr.1200, C. 1258 = floor layer C.008.

\section{The Roman Glass}

\section{Dominic Ingemark}


[Figure 22 near here]

The assemblage of six Roman glass sherds is typically small for native sites of Roman Iron Age date; in fact, excavations of many others have yielded only one or two sherds (Ingemark 2014, appendix A) (Figures 19 and 22). Despite being small in size, this assemblage features a very rare - in native contexts unique - find of a hemispherical cup in deep blue glass with traces of yellow enamel painting (SF003; Figures 19 and 22) In Romano-British contexts, vessels in strong colours like this are predominantly found on sites occupied from the time of the Claudian conquest to the early Flavian period (Price and Cottam 1998, 15). Continental finds of enamel painted vessels have a roughly similar range of dates, ranging from the Tiberian to the Flavian period (Rütti 1991, 123). In a paper on early enamelled glass Beat Rütti has pointed out that only two types of vessels produced in the early Imperial period were decorated with painted decoration: cups of cylindrical to hemispherical shape (so-called Hofheim cups; Isings (1957) Form 12), and amphorisks of Isings (1957) Form 15. Intact Hofheim cups are painted with different motifs: foliage, birds, fish, and mammals such as horses and deer. On the base are crudely painted stars or rosettes (Rütti 1991, figs 24-26). Only a very limited number of finds of enamel-painted Hofheim cups are known; Rütti mentions some thirty to forty finds from the entire area of the Roman Empire. Amphorisks of this specific type are also exceedingly rare; Rütti’s overview includes only two finds (Rütti 1991, 123-124, pl. 32a, pl. 33a and 34c). While the Dunnicaer find cannot be identified with absolute certainty, it strongly resembles a Hofheim cup in shape. Traces of painting in a colour and quality typical of this type of vessel strengthen the argument. The convex-curved fragment comes from the lower part of a cup; however, it is worthy of note that there is no trace of any horizontal wheel-cut or abraded line, which is a common feature of this type of cup. Finds of this early date decorated with enamel 
painting are very rare in Romano-British contexts (Cool and Price 1995, 63; Price and Cottam 1998, 33-34). From Colchester, Essex there is a fragment of a cup in yellowgreen glass decorated with a floral motif in red and yellow (Harden 1947, 297, pl. 87 no. 33). In Rütti's overview, a find of a Hofheim cup from London is mentioned, and this find is also cited in Hilary Cool and Jennifer Price's study of the glass from Colchester (Rütti 1991, 1991, fig 27; Cool and Price 1995, 63), but neither describes the vessel's colour. In addition, there is a possible find from Blackfriars Street, Carlisle, Cumbria. This small fragment is in peacock blue with painted decoration in red and yellow (Price 1990, 166).

Undecorated Hofheim cups in strong colours as well as in colourless glass are frequent finds in southern Britain, predominantly in contexts dating from the Claudian to the Neronian period (Price and Cottam 1998, 72). In contrast, relatively few finds have been made in later periods; there are, however, a limited number finds of Flavian date from northern Britain. From the Roman fortress in York there are a minimum of two cups in blue-green glass which belong to this class of vessels, plus possible single sherds in emerald green, light yellow-brown and pale green glass (Cool and Price 1995, 1563, fig. 735). From Castleford, Yorkshire there is a rim-fragment of a Hofheim cup in deep blue glass (Cool and Price 1998, 143, 157, fig. 52:46). From Carlisle, Cumbria, there is the aforementioned fragment in peacock blue from Blackfriars Street (Price 1990, 166), and from the annexe ditch of the Flavian fort there is a possible find in bluegreen glass (Cool 1992, 63-64, 67, fig. 10:13). At Inchtuthil, Perthshire, two fragments from a single Hofheim cup in pale yellow-green glass were discovered (Price 1985, 305, 308, fig. 93:2). This painted cup in deep blue glass - most probably a Hofheim cup reached native hands either in the pre-Agricolan period, or it was manufactured some decades earlier and came into native possession at the time of the early Flavian period, 
when the Agricolan invasion took place. Given the fact that vessels of this type are exceedingly rare in Romano-British contexts, the likelihood of this reaching Dunnicaer as a broken piece of glass found on an abandoned Roman site is extremely unlikely. Rather, this is likely to have come into native hands as an intact object.

Three fragments of blue-green bottle glass (SF001, 006 and 1011) representing a minimum of one, possibly up to three, cylindrical (Isings Form 51) or prismatic bottles (Isings Form 50), were also found (Figures 19 and 22). Although in a Roman context they had a primary function as containers for wine, olive oil and other foodstuffs, they often had a secondary function as durable and highly practical vessels that could be used again and again, sometimes for containing the ashes of the deceased (Ingemark $2014,132)$. In native contexts a number of glass finds show evidence of a tertiary use as gaming pieces or possibly polishers. Given that Roman drinking customs appear to have been imitated in native contexts, it is possible that they were exported beyond the Roman border with their contents, i.e. wine. After they were emptied, they had a prolonged use as containers, and eventually having been broken, they were in some cases either re-melted into beads and bangles, or were knapped into objects such as gaming pieces (Ingemark 2014, 133). One of the fragments of blue-green bottle glass from Dunnicaer is a reeded handle with multiple tooled narrow ribs (SF001). Angular reeded handles were found on both cylindrical and prismatic bottles. A roughly prismatic fragment of blue-green bottle glass is likely to represent either a polisher or a small gaming piece (SF1011). The third fragment (SF006), while from a cylindrical or prismatic bottle, is undiagnostic. In contrast to the rarity of the hemispherical cup, bluegreen bottle glass represents the single largest category of Roman glass found on native sites north of Hadrian's Wall (Ingemark 2014, 133); to date no less than thirty-eight sites with finds of this type have been discovered. They are very frequent in the Roman 
forts in northern Britain, and exceedingly common finds in the rest of Roman Britain (Price and Cottam 1998, 191-198). The earliest finds of both cylindrical and prismatic bottles in Romano-British contexts date to the Claudian period. While production of cylindrical bottles seems to have ceased around AD 110 (Price and Cottam 1998, 191), the production of prismatic bottles may have continued until the early third century (Cool and Price 1995, 184).

Two finds in colourless glass could not be identified to type. One may have come from a cup or beaker (SF016), the other from a small flask or a cup (SF021) (Figure 22). Colourless glass started to be produced in quantity in the last quarter of the first century $\mathrm{AD}$, and continued in the second and third centuries $\mathrm{AD}$ (Price and Cottam 1998, 16). Again, these vessels are likely to have reached Dunnicaer as intact vessels, for the chances of finding such small and fragile sherds on a Roman site would have been very limited.

In conclusion, the assemblage of six sherds of Roman vessel glass, represents a minimum of four, and up to six, vessels. In my view, there is much to suggest that the glass vessels reached Dunnicaer as intact vessels. The date range of these vessels is the first century $\mathrm{AD}$ - from the Claudian to the Flavian period - to the second, and possibly third century AD. One fragment was re-worked into a new object, either a polisher or a small gaming piece (SF1011). The wear on the other finds - on the upper and lower parts, but less on the edges - suggest that they were lying on the ground for some time and trampled upon. This glass assemblage consists of drinking vessels in the form of cups and beakers, and of vessels used for the storage and transport of drink in the form of bottles. This is typical for the glass assemblages in native contexts beyond Hadrian's Wall (Ingemark 2014, 179-181, fig. 4.5). The assemblage clearly represents a deliberate choice of imported Roman objects, and includes one very rare and presumably valuable 
object in the form of the hemispherical cup. Dunnicaer is by no means unique in including a type of glass vessel which is rare even in Romano-British contexts (Ingemark 2014, 181-182). For instance, a cast and lathe-turned vessel in opaque red glass (resembling a Samian bowl of Dragendorff type 27) of Claudian to Neronian date was found at Leckie Broch, Stirlingshire. From the same site came another rare, and early find, an amphorisk or flagon with marvered-in blobs (Ingemark 2016, 157). There are also a number of locations with finds of unusual pillar-moulded bowls in polychrome glass, vessels which are likely to have been manufactured in the first half of the first century AD (but which had a prolonged use): Traprain Law, East Lothian; Castlehill Wood, Stirlingshire, and Tealing, Angus (Ingemark 2014, 30-32).

\section{Catalogue}

SF001 Fragment of a reeded handle of flat shape from a cylindrical or prismatic bottle. Blue-green bottle glass, with occasional bubbles. Worn on both upper and lower side after it was broken. PH 24 mm; W (broken off, not representing the original width) 24 mm; WT 4.7 mm. C.002, silt near sub-rectangular strucutre.

SF003 Body fragment of a convex-curved vessel. Possibly the lower body of a hemispherical, so-called Hofheim cup/Isings Form 12. Deep blue glass with occasional small, round bubbles. Traces of yellow enamel painting, of a crude quality. Upper and lower surfaces heavily worn, probably after having been broken; the edges of the glass bear little traces of wear. 17 x 19 mm; WT $3.5 \mathrm{~mm}$. Tr.1, C.001, unstratified. SF006 Unidentified fragment of blue-green bottle glass, probably a body sherd. 5 x 4 mm; WT 3.0 mm. C.008, floor layers.

SF016 Curved fragment of a cup or beaker? Colourless glass with a matt surface; occasional round bubbles. 11,8 x 9.3; WT $1.0 \mathrm{~mm}$. C.064, pit [063] 
SF021 Curved fragment of a cup or small flask? Colourless glass with a matt surface. 10.3 x 6.6 mm; WT 0.3 mm. C.1200, unstratified.

SF1011 Unidentified fragment of blue-green bottle glass. The fragmented glass has a faceted shape and is heavily worn on all sides as a result of deliberate polishing. This may represent a polisher or a gaming-piece. $9,5 \times 9 \times 6.5 \mathrm{~mm}$. C.008, floor layers.

\section{Faunal Remains}

\section{Ingrid Mainland}

A small assemblage of animal bone was recovered from the 2015-17 excavations. All fragments were identified to species, anatomical element and body side whenever possible. Where species could not be ascertained, fragments were assigned to one of the following size classes: L.ung (large ungulate - e.g. cow, horse, red deer); S.ung (small ungulate - e.g roe deer, pig, sheep/goat); S.mam (small mammal-sized - e.g. dog, otter, cat); UNM (unidentified terrestrial mammal) and MAM (indeterminate mammal). Vertebrae and ribs were not identified to species or side and were grouped into one of the size classes above. Mammalian species identification was achieved using the modern reference collection at the Archaeology Institute, Orkney College UHI, and with reference to identification manuals such as Schmidt (1972). The presence of particular diagnostic zones on elements were noted, recording whether $50 \%$ or greater of the zone was present. All fragments identified to species were given an individual entry in the data record; fragments identified as L.ung, S.ung, etc. only required an individual entry if they possessed a diagnostic zone or were considered special in some other manner.

Epiphyseal fusion was recorded for all bones identified to species. All fragments were examined for signs of pathology, butchery, recent breaks, erosion, weathering, burning or canid gnawing. The colour of burnt bones was noted using the following 
categories after Stiner (et al. 1995): 0 - not burned (cream/tan); 1 - Slightly burned; localized and less than half carbonized; 2 - Lightly burned; more than half carbonized ; 3 - Fully carbonized (completely black); 4 - Localized half calcined (more black than white); 5 - more than half calcined (more white than black); 6 - Fully calcined (completely white).

\section{The Assemblage}

[Table 5 near here]

A total of 163 mammal bone fragments was recovered from Dunnicaer (Table 5). Of these, only 51 could be identified to species, all of which derived from cow (Bos taurus). The remaining fragments were predominately large ungulate-sized and are likely also to be cow.

The bone was in very poor condition, with a high degree of fragmentation and eroded surfaces, probably reflective of acidic soil conditions not conducive to bone survival. Most of the burnt bone was white, i.e. calcined, indicating combustion at high temperatures (Stiner et al. 1995). Burnt bone has a greater propensity to fragment and this will have also contributed to the bone fragmentation observed. Very little other can be ascertained from an assemblage of this size and the degree of fragmentation and the following merely lists bone representation by context.

Context 203: Fill of slot 217 - south-east rampart

Large ungulate long bone with evidence of butchery.

Context 212: Fill of slot 217 - south-east rampart

Cow lower first or second molar, in wear. Highly friable and fragmenting. 8 fragments of large ungulate long bone all of which were calcined (ie white) indicating combustion 
at high temperatures. There were additionally a further 10 unidentifiable fragments which had also been calcined.

Context 301: Lower terrace deposits

1 calcined large ungulate long bone and 9 unidentified bone fragments. These latter were eroded reflecting exposure to acidic soil conditions.

Context 408: TT4 disturbed contexts?

5 fragments of cow molar, likely all from the same tooth.

Context 1009: Lower terrace occupation

8 unidentified fragments in very poor condition, highly friable.

Context 1010: Hearth [1012] overburden

Two animal bones were recorded in context 1010: a femur shaft fragment (LHS) from a calf, foetal or neonatal in appearance, and a large ungulate long bone fragment. Neither of these were burnt.

Context 1011: Hearth [1012]

12 fragments were recovered from this context, all of which were burnt. 9 could not be identified, 2 were classed as small ungulate long bone fragments and 1 as a large ungulate long bone.

Context 1200: Floor layers upper terrace cleaning level 
24 fragments of animal bone from cow $(n=11)$ and large ungulate $(n=13)$. Diverse elements were represented: rib (1), humerus (1), long bone (10), a third phalange (1) and a tooth fragment (1). The phalange was identified as cow as were the fragments of loose teeth, which all derived from lower molar.

\section{Context 008: Floor layer upper terrace}

At 66 fragments, this is the largest deposit of bone recovered from Dunnicaer.

Unfortunately only 13 could be identified to species, all of which were identified as fragments of cattle molar most probably originating from a single fragmented tooth. The remaining bone was burnt white, ie calcined.

\section{Context 1255: Posthole/pit [1254]}

20 fragments of cow tooth, likely from a single molar.

\section{Discussion}

The small and very poorly preserved assemblage of animal bones from Dunnicaer is dominated by cattle. The presence of a neonatal or foetal animal may indicate the housing of animals in the vicinity of the settlement or the use of calfskin. Most of the assemblage had been burnt at high temperatures prior to deposition. The association between this material and hearth deposits suggests an origin in domestic fires and/or routine refuse disposal. A similar emphasis on cattle is seen at other Late Iron Age and Pictish settlements in the North of Scotland, including Portmahomack (Seetah 2016), Rosemarkie (Kennedy 2017) and Rhynie (Mainland in prep). This contrasts with husbandry patterns in the Northern and Western Isles, where sheep tend to be more 
common (Smith 1994; Bond 2007). Although this raises questions about regional variation in the nature of human-animal interactions across Roman and Late Iron Age Scotland, the Dunnicaer assemblage is unfortunately too small and poorly preserved to determine whether these observations are significant. Larger faunal assemblages, perhaps targeted directly on any well preserved midden deposits, are required to facilitate better understanding of animal husbandry and/or the roles of animals at Dunnicaer and other similar sites in Mainland Scotland.

\section{Radiocarbon Bayesian modelling}

There is a total of 21 radiocarbon dates from the excavations at Dunnicaer (Table 3).

The samples were all single entities of short-lived material to avoid any potential problems with mixing and/or in-built age offsets (Ashmore 1999). The samples were submitted for radiocarbon dating by accelerator mass spectrometry (AMS) to the Poznan Radiocarbon Laboratory. The Poznan laboratory generally follows the same pretreatment procedures as the Oxford Radiocarbon Accelerator Unit (Brock et al. 2010). The results are presented as conventional radiocarbon ages (Stuiver and Polach 1977), quoted according to the international standard set at the Trondheim Convention (Stuiver and Kra 1986). The date ranges in Table 3 and in plain text have been calculated using the maximum intercept method (Stuiver and Reimer 1986), and quoted with the endpoints rounded outward to 10 years. The probabilities given in the figures were calculated using the probability method (Stuiver and Reimer 1993). The calibrations used the internationally-agreed calibration curve of Reimer et al. (2013) for terrestrial samples (IntCal13), and were calculated using OxCal v4.3 (Bronk Ramsey 2009). These dates were modelled following a Bayesian approach to chronology building (Buck et al. 1996) and the model is described below. 
Specific contextual details for the dated samples are given above. A description of how these contexts are grouped together or any specific stratigraphic relationships between dated contexts are given here. To start, Poz-71940 produced a post-medieval result and is likely from later activity associated with this feature, as described above. As such, it is excluded from all modelling.

The chronological model is based on a separation of the archaeological deposits into four 'areas'. There are three radiocarbon results (Poz-71936-7 and -84480) from two contexts (202 and 1802) that are related to the rampart. In the initial chronological model, these samples are considered to accurately date the rampart construction, though an alternative reading of the taphonomy suggests that these samples are likely to be redeposited and provide only a terminus post quem for the rampart construction. [Figure 23 near here]

The remaining results are from areas in the Upper and Lower Terraces. The Lower Terrace has radiocarbon results (Poz-71938, -84476) from contexts 301 and 1013, respectively. The Upper Terrace has been split into the East and West areas, and these areas contain small elements of stratigraphy between sampled contexts. In the East Upper Terrace area there are five samples that come from stratigraphically unrelated features. They include: Poz-84477 (1203); Poz-71942 (509); Poz-71939 (406); Poz98953 (028); and Poz-98949 (007). There are a further five results from stratigraphically-related contexts. At the base of the sequence there are results (Poz98951 and -98958) from contexts (020) and (101), respectively. While these two contexts are not stratigraphically-related, they are both earlier than the results (Poz98950 and -84479) from contexts (008) and [003] (005), respectively. Context (1265/005) is cut/overlain by context 1263/006, which was also radiocarbon dated (Poz84478). Within this defined sequence, the result (Poz-98958) is more recent than all of 
the overlying material and likely represents intrusive material, and as a result is excluded from further modelling. There are five dated samples from the West Upper Terrace area. Three samples have no stratigraphic relationship between the context they date (Poz-98956-7, and -98959, contexts 079, 141, and 081, respectively). For two samples, a stratigraphic sequence did exist, with Poz-98954 (context 069) from a lower context than Poz-98952 (context 021).

[Figure 24 near here]

The model has good agreement (Amodel=85) between the radiocarbon dates and the prior archaeological information. The model estimates activity at Dunnicaer began in cal AD 105-225 (95\% probability; Figure 23; start: Dunnicaer), and probably in cal $A D$ 155-215 (68\% probability). The dated activity ended in cal AD 350-450 (95\% probability; Figure 23; end: Dunnicaer), and probably in cal AD 375-425 (68\% probability). The overall dated use of the site was $140-325$ years (95\% probability; Figure 24; span: Dunnicaer), and probably for 175-260 years (68\% probability). The last function was used within $\mathrm{OxCal}$ to calculate the latest probability from the results associated with the rampart, as a way to provide an estimated date by when the defences were constructed. The modelling estimates construction in or by cal AD 245380 (95\% probability; Figure 23; build: rampart), and probably in or by cal AD 285340 (68\% probability). The alternative model, with the rampart dates included as only providing a tpq for the rampart construction, also has good agreement (Amodel=85). The start, end and span probabilities show no appreciable difference to the primary model, thus confirming the robustness of the primary model.

\section{Discussion}

\section{Coastal erosion at Dunnicaer}


The 2015-17 excavations leave little doubt that we are dealing with a heavily eroded site at Dunnicaer. Hearths on the upper terrace had been partly truncated by erosion and the rare survival of a sub-rectangular building was only partially preserved with one side entirely missing due to collapse of the cliff on the northern side of the settlement. Thomson $(1859,71)$ was of little doubt that the stack was eroded - he identified the adjacent projecting dyke ('about 100 feet distant') and stated that it was 'impossible to doubt that, a few centuries ago, it and the pinnacle were united'. Thomson also identified the source of erosion at Dunnicaer - soft veins of sandstone that erode quicker than the hard conglomerate, forming tunnels or arches through the stack that ultimately collapse. Thomson stated:

One of these has been washed out, and left a large block separate from the principal pinnacle on the land side. Another similar, has been so far washed out as to make an irregular arch, through which one can easily walk. And I noticed another, which to all appearance, will in a few years form another passage. The roofs of them will in time fall in, and, ere long, Dinnacair itself will probably disappear. (Thomson $1859,71)$

[Figure 25 near here]

There is little today left of the large block on the landward side that Thomson mentions other than an irregular stump of rock a few metres high. There are also now at least three different areas in which erosion has created tunnels through the existing stack (the westernmost of which now has a crack in the rock extending to the very top of the stack). The veins of eroded sandstone can be seen in the footprint of eroded rock around the stack today - a particularly large vein has been removed on the north side, which may have been a tunnel into the rock that at some point collapsed and led to the loss of the north side of the stack (Figure 25). Perpendicular veins can also be seen running 
south-west/north-east in five different locations, including immediately east of the eastern base of the lower terrace - collapse here has clearly led to the truncation of any buildings that may be argued once existed on the lower terrace.

[Figure 26 near here]

Cartographic information on Dunnicaer is limited for there are no maps that date prior to the nineteenth century. A Hydrographic Office survey of 1833 is not particularly detailed, however, it appears to show a larger stack at Dunnicaer and another stack on the south side of Strathlethan Bay at Carlin Craig that no longer exists (Hydrographic Office 1844). The first edition Ordnance Survey (OS) six-inch map (surveyed 1865, published 1868) appears to show the main stack that survives today with a further stack immediately to the north, which is simply a stump of rock submerged at high tide today (Figures 25 and 26). However, the first edition OS 25-inch map shows this second stack as low rock. It is not certain why the maps differ as they were surveyed and published in the same years, but there can be no doubt that this second rock must have at some point been part of the larger stack at Dunnicaer and had become subsequently separated through the erosion of a weaker vein of sandstone. The first edition maps also show that other elements of the coastline were more substantial than today - the adjacent Bowduns promontory, for example, is depicted as being more extensive with a projecting finger of land depicted on the headland whch has now almost completely eroded.

Admirality Chart 1443 from 1884, like the first edition six-inch map, suggests two surviving stack portions at Dunnicaer and that the main stack was substantially larger than today, extending further seawards (Hydrographic Office 1884). The discrepancies in the maps might suggest some ambiguity in classification as to whether the smaller isolated stack was still land or not. Certainly by 1902 the second stack is 
shown on the six-inch second edition OS map as a stump of rock in the sea with no surviving land surface - as it is today. The 1:25,000 Ordnance Survey map of 1957 shows Dunnicaer as having a similar outline to the present day.

Overall, the maps only provide limited (and at times conflicting) testament to the effects of erosion, but given the highly truncated nature of the buildings and features on the stack there can be no doubt that erosion has had a very serious effect. The Scottish Government Dynamic Coast mapping project (Dynamic Coast 2019) identifies up to 010 m of erosion on the coastline next to Dunnicaer between 1890 and 1970 and a similar rate between 1970 and present. However, the specific effect on Dunnicaer is difficult to quantify. The variable geology of Dunnicaer undoubtedly made it very susceptible to erosion. As Thomson noted $(1859,71)$, it is the veins of sandstone that comprise part of the geological makeup of the stack that make it so prone to erosion. The erosion of these seams of sandstone can lead to catastrophic collapse. This is a process which is currently evident on what remains of the stack, with the erosion of one channel of softer sandstone having formed a large tunnel through the body of its base it is erosion events such as these that will lead to the collapse of the limited remains still present.

Estimating what we have lost at Dunnicaer is almost impossible, but it seems likely that the site extended at least to encompass the footprint of eroded rock evident at the base of the current stack. If it had extended this far seawards, then the promontory would have been at least $115 \mathrm{~m}$ long and perhaps as much as $160 \mathrm{~m}$; and at least $50 \mathrm{~m}$ wide at its broadest (c.0.4 to 0.5 ha in total area) (Figure 25). However the remaining rock footing may only be a fragment of the original extent, with softer areas of rock clearly completely removed as is evident on the northern side of the stack with a channel having been completely eroded between the surviving stack and an area of 
eroded rock on the north side. If the site extended only to the current footprint of eroded rock at the base, i.e. the site extended c.40 m further out to sea it would only take an erosion rate of around $0.025 \mathrm{~m}$ per year to reduce it from its earlier first millennium AD extent to its current outline/position. However, as well as gradual erosion, it is likely that the site suffered intermittent catastrophic episodes of collapse following the erosion of sandstone veins (cf. Crane and Murphy 2010, 58). Overall, it is impossible to estimate the original size of the site at Dunnicaer other than to say it is likely to have been substantially larger than today and that erosion caused by the softer veins of sandstone within the bedrock here is likely to have had a major effect on the survival of major portions of the site in the past and it is this feature of the geology that will form the main threat to the continuing survival of archaeological deposits.

Erosion is a major threat to many coastal promontory sites across Scotland. The Scharp (Scotland's Coastal Heritage at Risk) website, lists a number of promontories as high-priority locations for mitigation work in advance of coastal erosion (Scharp 2018), including examples in eastern Scotland. Around $25 \mathrm{~km}$ south of Dunnicaer coastal erosion has removed most of the fifteenth-century castle on the coastal promontory at Kaims of Mathers (NRHE No. 36337). Another example is Newark Castle set on a promontory on the south coast of Fife, where coastal erosion has led to the loss of the entire west side of the fifteenth century castle (NRHE No. 34203). Major coastal erosion is also affecting the sixteenth century coastal fort at King's Mount, Eyemouth, Scottish Borders (NRHE No. 60188) and is undermining Dunbar Castle in East Lothian (NRHE No. 60188).

Looking further afield, recent work on the Moray coast to the west at Burghead, suggests very substantial erosion on the major early medieval promontory fort. Mapping of the Burghead coastline undertaken as part of the Scottish Government National 
Coastal Change Assessment suggests that there has been approximately $7.9 \mathrm{~m}$ of erosion on the north-west side of Burghead fort since 1904, with over $2.5 \mathrm{~m}$ of erosion happening between 1976 and 2011 (Dynamic Coast 2019). This rate of erosion, which is increasing, implies that within the next few decades, the enclosing elements of the seaward side of the fort with its very substantial timber-laced ramparts will be completely removed - current mitigation works aims to record the seaward ramparts prior to further erosion.

Coastal erosion is also a major issue in the Northern Isles of Scotland where coastal change has seriously impacted on a number of promontory, islet and stack sites in the Northern Isles. The erosion at the important Viking and Pictish settlement at Brough of Birsay, Orkney, has been described as 'appalling' by Anna Ritchie (See description in Ritchie 1996, 116-119), while at Hog Sound in eastern Shetland the effect has been extraordinary, and a channel some $18 \mathrm{~m}$ wide has opened up immediately behind the defences to reduce the greater part of this large promontory fort to an inaccessible island (NRHE No. 1293).

Further afield, in Ireland, a prominent example of coastal erosion in relation to a promontory fort hit the headlines in 2018. A winter storm at Dunbeg, County Kerry, Ireland in January of that year removed a $10 \mathrm{~m}$ section of the enclosing rampart of a promontory fort that is protected as a national monument and managed by the Office of Public Works as not only an important archaeological monument, but also a tourist attraction (Pollak 2018) (See Barry et al. 1981 for the excavation report). The storm also destroyed the entranceway to the fort and part of a souterrain. Other erosion has been recorded on numerous occasions since the site was first mapped in 1841, with as much as $50 \%$ of the surviving landmass being lost to the sea since the nineteenth century (Dunne 2014). 
In Wales, coastal mapping on promontory forts has been undertaken in Wales for more than a decade (See also Cherish 2019). The Dyfed Archaeological Trust reported in 2009 on significant levels of erosion at a number of sites (Page et al. 2009). At Porth y Rhaw, Solva, Pembrokeshire, one of the few promontory forts excavated in Wales in recent decades it has been estimated that nearly $80 \%$ of the promontory has been lost since the Iron Age - only 0.1 ha survives of an estimated 0.45 ha originally enclosed by a complex series of ramparts and ditches (Crane and Murphy 2010, 56-58). Erosion has been slow since the first detailed plan of 1889 , but the evidence suggests catastrophic loss in the past with erosion along the Pembrokeshire coastline tending to happen through sudden landslips and cliff collapses (Crane and Murphy 2010, 58). Another spectacular example of erosion is Black Scar in Pembrokeshire, where severe erosion has removed substantial parts of the defences that were marked on the OS $1^{\text {st }}$ edition map. A chevaux de frise, formerly visible below the bank of the fort is now also lost to erosion (Lock and Ralston 2017, WA2007). Coastal erosion has also affected coastal forts in England, none more so than the $6+$ ha fort at Flower's Barrow, on the Dorset chalk where at least $50 \%$ of a contour fort has been lost to the sea (Brown 2009, 186). Overall, there is little doubt that coastal erosion is a major threat to the survival of many coastal forts across Britain and Ireland and there is a good case for identifying promontory and stack sites in particular as one of the most threatened archaeological resources in existence.

\section{Dunnicaer and its parallels}

[Figure 27 near here]

Clearly the site at Dunnicaer is much eroded. As outlined above, estimating the original size is fraught with difficulties, but the surviving footprint of the site suggests it could have been much larger- perhaps around 0.4 ha in extent and is likely to have been 
joined or at least more accessible from the mainland than is the case today (Figures 25 and 27). The extreme levels of erosion makes reconstruction difficult - however, Stuart's description of the circumstances of the discovery of the stones is interesting: The fragments at Stonehaven are said to have formed part of a wall which surrounded the top of an insulated rock called Dinnacare. (Stuart 1856, 14; our emphasis). Thus, in the nineteenth century it was thought that the enclosing wall originally went all around and indeed the presence of a rampart on the south side of the stack is best interpreted as a surviving fragment of an enclosing wall that would originally have enclosed the promontory. Mr Christian's letter to Thomson makes it clear that a stone wall was found on at least one side of the stack - he described a low wall 'along part of the edge' that was 'regularly built' (Thomson $1859,70,74)$. The only evidence for walling found in the excavations was the fragment of the sub-rectangular building found on the west side of the stack and the remains of the timber-laced or timber-framed rampart on the south side. The wall of the sub-rectangular building was generally modestly built and its position would not accord with it forming part of a wall being along the edge of the stack. In contrast, the remains identified on the southern edge of the stack provide the most convincing enclosing work that could be described as a wall surrounding the site. Indeed, the excavations on the southern side of the stack showed clear evidence for a complex enclosure wall defining the southern edge of the upper terrace of the sea stack. Evidence for beam slots, postholes and stone elements, along with a stone foundation in places, suggest a substantial timber-laced or timber-framed rampart existed here. The evidence suggests a rampart at least $2 \mathrm{~m}$ wide, though it could have been more substantial given the erosion all around the stack and no outer face was identified, presumably lost to erosion on the seaward side. This rampart had very clearly been extensively robbed with most of the stonework no longer in situ or present. This 
may tally with the reports in Thomson (1859) that locals knew this place as a source of good building stone. Certainly the stonework identified in the excavations in association with the rampart on the north side of the stack was of very good quality, comprising regular blocks of sandstone that were clearly not from the immediate locality where the bedrock is conglomerate. The beam slots and charred timbers also provide clear evidence for substantial investment in labour and resources in order to enclose Dunnicaer. The place-name evidence also strongly implies that this was a fortified promontory, an interpretation that tallies with early interpretations of the site. [Table 6 near here]

Enclosing the entire promontory or stack, as suggested above, is unusual in the promontory fort corpus - more common are enclosing elements that simply cut off one side of promontories from the landward side (See Table 6). It could be that the rampart identified on the south side was designed to protect the site from the adjacent and overlooking promontory of Bowduns. However, Bowduns is over $50 \mathrm{~m}$ away, and it is unclear what protection a rampart would provide from attack. The presence of a rampart on this side is instead suggestive of an enclosing boundary that went all the way around the settlement. There are only a few clear parallels for such an arrangement, the most obvious being Burghead, Moray, where the enclosing elements of probable sixth/seventh to the tenth century AD date surround the entirety of a much larger promontory (Oram 2007). Other examples may include Green Castle, Portknockie, where a rampart extended at least along the south-east side of the promontory, and though excavations on the seaward side failed to detect any enclosing elements on this side, erosion may have been a factor (Ralston 1987, 21; Ian Ralston personal communication, April 10, 2018). Broad Haven, Aberdeenshire a 0.07 ha promontory enclosure also has evidence of an enclosing wall around the north and east sides of a 
narrow promontory, though the remains are compromised by later use of the promontory as a firing range (Table 6). Dundonnie, also in Aberdeenshire, has a low bank that extends along a substantial portion of the stack, but is focused on the landward side. Further afield, the remains of a bank along the western side of Siccar Point, Berwickshire, was recorded by Kinghorn (1935, 157, Fig. 1), in addition to the southern, landward side, rampart.

The beam slots on the south side of Dunnicaer have been interpreted as part of a timber-laced rampart. A good parallel for this is the timber-framed wall found in better preservation at Green Castle, Portknockie (Ralston 1980, 1987). The rampart at Green Castle had been burnt preserving the detail of the timber framework. This was constructed using a framework of squared timbers that included transversal, longitudinal and vertical elements that were largely not earthfast (Ralston 1987, 22). At Dunnicaer the linear beam slots only occurred in places and were of differing depths - it is likely this was due to the uneven ground surface, with parts of the promontory edge needing to be built up (as in trench 1800)- possibly indicating that as at Porknockie that the rampart consisted of a framework that was pre-fabricated and transferred into place as complete sections (cf Ralston 1987, 22). However, it cannot be definitively proven whether the rampart was timber-laced (with horizontal timbers only) or fully timberframed and given the truncation of the wall-faces and wall-core it was impossible to establish one way or another.

Looking at parallels more generally, in addition to Dunnicaer there are 30 promontory/stack enclosures recorded in the National Monuments record and Atlas of Hillforts along the eastern coast of Scotland in the area from Fraserburgh to Berwickupon-Tweed (Table 6). Generally, little is known about the defences of these with excavations rare. These forts are almost all under one hectare in extent. The three 
exceptions are Dunnottar at 1 ha, Dundonnie at 1.1 ha and a possible outer ditched enclosure at Dunbar. In the Annals of Ulster, seiges of Dunnottar are referred to in both AD 680 and 693 (Mac Airt and Mac Niocaill 1983: 146, 154; Fraser 2009: 214). There are also references in the Chronicles of the Kings of Alba to the killing of Donald son of Constantine (AD 889-900) by the "heathen" at Dunnottar (Woolf 2007: 123, 125), and to Æthelstan, king of the English, raiding with his land forces as far north as Dunnottar in 934 in the northern English Historia Regum Anglorum (Woolf 2007: 161). Today the site is crowned by the remains of a spectacular $14^{\text {th }}-17^{\text {th }}$ century castle. Excavation of a trench excavated on the northern side of the promontory in 1984 failed to identify any early medieval deposits or defences (Alcock and Alcock 1992). At 1 ha, Dunnottar would be one of the larger early medieval fortified sites known in Scotland, but what the character of the defences were remains uncertain, as is the date at which it was occupied and defended prior to the construction of the later castle. Dundonnie is unexcavated and there have been no finds to hint at the date of the enclosing works. At Dunbar, a triple ditch system of probable Iron Age date is known and a rampart of the $7^{\text {th }}$ century cut off a larger area of around half a hectare (Table 6). A further ditch excavated in 1998 has been identified that may have enclosed as much as 2 ha though only a small section was revealed by development-led excavation (Moloney 2001, 236). Very few of the promontory forts of eastern Scotland are dated (Table 6). An earlier Iron Age date has been obtained from the outermost ditch of four at the 0.5 ha promontory fort at Castle Dykes, Borders (Morrison 2003, 114). The earlier phase of enclosing elements at Dunbar are also likely to date to the earlier Iron Age (Perry 2000, 21 ), and there is a radiocarbon date of $1^{\text {st }}$ century cal $\mathrm{BC}$ to cal $\mathrm{AD} 1^{\text {st }}$ century AD from the upper ditch fill of the possible 2 ha enclosure. There are also early medieval dates from Dunbar, with an enclosing rampart and possible ditch likely to be seventh century 
AD in origin (Perry 2000, 58-59). The enclosure at Auldhame appears to be contemporary with the Anglo-Saxon church and earlier phase of the cemetery inside, with the ditch interpreted as the vallum for a monastery, though the earliest phases of the ditch were not dated and could have been part of an earlier promontory fort (Crone and Hindmarch 2016, 136). At St Abb's, excavations by Leslie Alcock identified two lines of palisade, one burnt, under a complex rampart, at a location linked with the monastic site of Colodesbyrig/Colodaesburg, referred to in various Anglo-Saxon sources (Alcock et al. 1986, 262-266). Alcock argued that the palisades may have related to a secular fortification (also referring to the place-name element, burg, fort) that pre-dated the monastery. However, this is uncertain and the palisade trench returned terminus post quem dates of the seventh to eighth century AD which would fit with the likely chronology of the putative monastery.

In terms of contemporary sites to Dunnicaer, there is evidence for Roman Iron Age occupation at four coastal promontories in eastern Scotland. Childe's excavations at Earn's Heugh in the Borders recovered Roman objects of first to second century AD date, though these were from the internal roundhouses that may be late in the overall sequence of the enclosure complex (Childe and Forde 1932, 182). Roman Iron Age finds have also been recovered from West Mains of Ethie, Angus. West Mains of Ethie was excavated by the Abertay Historical Society from 1962 to 1971 . The site is enclosed by three ramparts, each with an external ditch entered by a central causeway (Wilson 1980,114). The excavations revealed a number of hearths, postholes and areas of paving inside the ramparts. Finds included a penannular brooch from a palisade trench, a glass bead and bangle from the entrance causeway, stone lamps, an iron sickle, a bronze fibula and a sherd of samian. The typologically datable finds are of first to second century AD type (Wilson 1980, 118). Judging by the scale of the ramparts vis-à- 
vis the area enclosed it seems likely that erosion has destroyed a significant part of the fort.

Further south, an enigmatic, and perhaps again much eroded, Roman Iron Age coastal site is represented by finds from The Gegan, East Lothian. The Gegan is a detached rock islet to the east of Auldhame (Table 6). It is clearly land that was once attached to the mainland as part of a projecting promontory, though again how long ago is uncertain. During excavations in 1870 the stone wall foundations of sub-rectangular building were identified on the small islet (Laidlay 1870). The structure found comprised a low stone wall with internal paving and a central drain. A number of human bones and a large quantity of animal bones were found within and around the building. Finds included bone tools, a bone comb decorated with a crescent and circular motifs, most of a first or second century Roman amphora and a serpentine playing piece of Roman provenance (Robertson 1970, table 5). A sherd of Roman glass is said to have come from Castle Dykes, Bilsdean, East Lothian, but no excavation has been conducted at this fort. Overall, none of the slim dating evidence from these examples stretches into the third to fourth centuries AD contemporary with the later phases of Dunnicaer, but a third to fourth century phase at Dunnicaer would be difficult to ascertain on object dating alone.

Fortified sites of Roman Iron Age date in Scotland are difficult to identify more generally. There is radiocarbon dated occupation at a number of forts, but little evidence for enclosing elements of this date, particularly stretching into the third and fourth centuries AD. There was Roman Iron Age occupation at Eildon Hill, Borders (Owen 1992), but whether these phases were enclosed during this period remains uncertain. Likewise, the Roman Iron Age phases from Traprain Law, East Lothian, lie within a series of enclosure systems, but enclosing elements dating to the Roman Iron Age have 
yet to be identified, though there may be a fifth century enclosure phase. There are late Roman finds from Dumbarton Rock, West Dunbartonshire; Broxmouth, East Lothian, and Edinburgh Castle, Midlothian, but whether these relate to a phase of enclosure of the same date again remains uncertain (Hunter 2007, Appendix 2). Looking at promontory or coastal forts elsewhere in Scotland, there are sherds of samian from a contour enclosure at Little Dunagoil, Bute, but again the defences are undated (Marshall 1964). Generally, there is very limited evidence for fortified sites during the Roman Iron Age in Scotland. After c.200 cal BC there are few well dated forts in Scotland till a 'second generation' of forts of the fifth century AD or later (Noble et al. 2013, 1143).

Moving beyond Scotland, there are a small number of promontory forts in Wales with Roman material. Excavations at Porth y Rhaw Camp, Pembrokeshire, a severely eroded promontory fort has recovered Roman tableware indicating occupation into the fourth century AD (Crane and Murphy 2010). There are also Roman finds from promontory forts at Dinas Fach, Solva, Pembrokeshire and Sudbrook Camp, Monmouthshire (Lock and Ralston 2017, WA1978; WA2429). A more unusual location is Gateholm, Pembrokeshire, a c.4.7 ha islet site with around 110 rectangular buildings with a rampart and gate at the north-western tip of the island. Finds from limited excavation of the huts suggest late Roman to early medieval occupation (Lethbridge and David 1930; Wessex Archaeology 2010). There are a handful of promontory forts with Roman Iron Age phases in south-west England in Cornwall, these include the c.1 ha forts at Maen Castle and Penhale Point and the larger c.3 ha examples at Trevelgue and The Rumps (Lock and Ralston 2017, 0647; 0649; 0656 and 0654). In Ireland there are in excess of 500 recorded coastal promontory forts. Most of these enclose an area of under 1 ha. Few have been excavated with most producing little in the way of diagnostic artefacts or samples that could be used to date their construction. 
One impressive fort with Roman material is the 16 ha multivallate promontory fort at Drumanagh, Co, Dublin, which has revealed a significant quantity of Roman artefacts. Most of these finds remain unpublished, but there are first and second century AD pottery and coin finds, ingots and a seal box (Daffy 2013, 95-99). The defences, however, remain undated. At 16 ha we are obviously dealing with a different phenomenon at Drumanagh to the much more modest site of Dunnicaer. Indeed, with examples like Drumanagh, Dowling has suggested that the finds suggest parallels with coastal trading centres such as (the largely pre-Roman) site of Hengistbury Head in Dorset (Dowling 2011: 229). Likewise, Gateholm in Wales with hundreds of structures may have also had played the role of a trading settlement during the Roman period, albeit in this case within the Empire. At these locations the occupants are likely to have had a closer relationships with the Roman Empire than was possible at Dunnicaer, located further north of the frontier.

\section{Structures}

The structures within the fort at Dunnicaer are some of the few identified structures from eastern Scotland of the late Roman Iron Age. After the third century AD, the settlement record in eastern Scotland becomes exceptionally difficult to trace (Hunter 2007, 48-50). The occupation on the lower terrace at Dunnicaer comprised two hearths, one on top of another, with compacted floor deposits in the immediate vicinity. There were no obvious postholes associated with these hearths, implying the successive structures were built with turf walls or alternatively the structure was quite large and the main structural elements have been lost to erosion or lay outwith the limits of the trench. The main area of the upper terrace had two zones of concentrated activity. In the east this comprised a series of hearths surrounded by floor deposits that survived in a shallow hollow, and a series of cut pits and postholes. The digging of several larger pits 
is likely to be amongst the earliest events in this area, with these perhaps used as rubbish pits for structures elsewhere on the stack or by structures removed by later occupation. The number of hearths and postholes in this area imply significant reworking of this area with buildings constructed, reworked, demolished and rebuilt. To the west of this was another concentration of hearths - the fragmentary remains of at least four different hearths, some overlying each other and being cut or overlying other features. Some of these were overlain by a late sub-rectangular building. The palimpsest of features in such small areas of the surviving interior suggests intense activity on the stack. This intensity might have been caused by the settlement expanding through time, with an early palisade setting ([078] and possibly [033]) on the landward side with a hearth overlying [078] also suggesting settlement expansion with the access having been pushed further landward.

Reconstructing the form of the structures associated with the occupation on the headland is difficult. Despite the inaccessibility of the location, records of cultivation and known stone-robbing in the nineteenth century have obviously had an effect on the survival of the settlement. Nonetheless the lack of deep foundation posts for any of the structures indicates a different building tradition than the typical roundhouse of the Iron Age. The buildings appear to have included few earthfast elements, and turf outer walls that had in some cases stone foundations (cf. Carver et al. 2016, 86). The latest building identified [011/015] was obviously of sub-rectangular form, and one possible subrectangular post-built structure can also be identified, but the shape and character of most of the structures represented by the other hearths remains uncertain. Nonetheless, the sub-rectangular structures that are identifiable are rare occurrences of buildings of this date and character and indicate early adoption of the rectangular form in eastern Scotland. 
The transition towards more rectangular forms of building in the first millennium $\mathrm{AD}$ is a change that has generally been poorly understood in northeastern Scotland. Rectangular and sub-rectangular buildings are found at Rhynie, Aberdeenshire, in fifth to sixth century contexts (Noble et al. 2019, 69-70). Recent dating of archive material from Clatchard Craig, Fife, by the University of Aberdeen suggests that a probable rectangular building there is likely to be of seventh century date (Close-Brooks 1986, 145). Few earthfast elements of the building survived at Clatchard Craig, but floor layers and the position of a pivot stone for a door would suggest a rectangular building of around $9 \mathrm{~m}$ by $5 \mathrm{~m}$. Rectangular architecture was certainly in use by the late first millennium AD in eastern Scotland (e.g. Dunwell and Ralston 2008, Chapter 7), but the evidence from Dunnicaer may indicate an early adoption of rectangular domestic architecture in eastern Scotland, substantially earlier than more westerly regions such as Ireland (O'Sullivan et al. 2014, 93). The excavation of sites like Dunnicaer can help fill major gaps in the settlement record since the character of the buildings there has important implications for the identification of (or understanding the lack of evidence for) buildings of this type and date elsewhere in eastern Scotland. The limited preservation of the internal structures at Dunnicaer makes it difficult to address definitively whether any of the buildings were residences, workshops or more specialized buildings, but the presence of objects such as spindle whorls and a quern stone and the presence of developed floor layers where preservation was best would suggest that these were domestic buildings, though the presence of smithing evidence from the floor layers in the upper terrace suggests that this structure at least was used at times for metalworking.

The Finds assemblage

Gemma Cruickshanks and Fraser Hunter 
The Dunnicaer assemblage is small but diverse, providing a wealth of evidence about activities taking place within the settlement and the inhabitants' connections with the wider world. The rotary quern and pottery sherds encrusted with burnt residues provide glimpses of everyday food production and cooking. On-site stone tool manufacturing is evidenced by an unfinished spindle whorl, while an intact whorl illustrates yarn spinning was taking place. While production of simple stone tools and yarn would have been regular craft activities, metalworking required more specialist knowledge and equipment and is likely to have been more restricted. The two burnishers indicate that non-ferrous sheet metalworking was taking place. It is impossible to know what was being manufactured; a range of vessels, fittings and ornaments could be fashioned from sheet metal. Fragments of ironworking debris suggest some blacksmithing was also taking place (and there is the possible ingot mould on Dunnicaer No.1). Small-scale blacksmithing evidence is the most common form of ironworking evidence for Iron Age Scotland (Cruickshanks 2017; Hunter 2015, 233), and it is likely that the range of skills practised by the occupants of most settlements would have allowed casual repairs if needed.

A range of raw materials was exploited at Dunnicaer. Stone items were manufactured from locally available stone types, and the handmade pottery is likely to have been made from local clay. In contrast, Roman pottery and glass indicate material arriving here from much further afield. The Roman coarsewares are of later second to third century date, and the bottle glass can only be broadly dated as first to third century, but the samian sherd dates to the later second century and one glass sherd to the later first. The condition of some pieces indicates extended lives - the samian had been cut down and reused, as had one of the glass sherds, but the early (and highly unusual) 
glass sherd shows no such signs of a long life, and document early phases (first to early second century AD) to the site.

Parts of at least three Roman ceramic vessels and between four and six glass vessels are represented amongst the surviving finds. This includes some of the most frequently found Roman items from native sites - samian and blue-green bottle glass (Hunter 2001). In contrast, the deep blue hemispherical cup is a rare find which indicates the inhabitants had access to a wider range of Roman goods than was the norm. Ingemark argues the rarity of the single sherd of Hofheim cup suggests it came to Dunnicaer (or at least the area) as a vessel rather than a fragment. It fits a wider pattern he has noted of unusual or rare material being preferentially found on indigenous location compared to Roman ones (Ingemark 2014, 181-2).

The Dunnicaer finds are a good example of the complexities of interpreting Roman material from indigenous sites, and the varying life cycles they will have gone through. The three joining sherds of a Roman coarseware vessel indicate it was used as a vessel within the settlement (and its condition is similar to the local pottery), whereas one glass sherd and the samian had clearly been reshaped. The reshaping of samian in indigenous contexts beyond the frontier has long been recognised (e.g. Robertson 1970, 208; Campbell 2016, 225-8). It is noteworthy that it is typically samian, not other pot forms, which was habitually reshaped; there was something particular about this soft red pot. Glass sherds, in contrast, were much more rarely reshaped (Ingemark 2014, 186), though of course may have been reused through remelting. As Wallace notes, however, it remains uncertain when and where much of the material was broken and (in some cases) reused. It is worth noting also that, of the ten locally produced vessels identified, five of those are likewise represented by only a single sherd; the presence of only single sherds of Roman finds has become somehow totemic in current discussions about the 
presence of intact vessels as opposed to token fragments, but single sherds are in not in fact uncommon in Iron Age pottery assemblages.

The potentially extended lives of some of the finds complicate their discussion, but they represent a broad import range in local terms. Using metrics we have applied elsewhere (Hunter 2001), four categories of finds are represented (fine ware, coarse ware, glass container, glass drinking vessel). Roman goods are rarer north of the Mounth than to the south, and while the quantities are small, the range from Dunnicaer is rich in local terms (the nearby Aberdeenshire material is reviewed in Hunter 2016). While the samian has clearly been reused, the other finds point to material arriving in both the late first century and the third century, but there are no fourth-century finds, although it is likely the location saw use in that period. One of us has argued that the rarity of late Roman finds in much of north-east Scotland indicates a deliberate Roman policy of targeting and then spurning key areas, with destabilising effects (Hunter 2007, 2014, 208-9). While the basic pattern still holds, indications of a more nuanced picture are emerging, with selected areas showing late Roman contacts within this zone (e.g. Hunter 2016, 55) (See also discussion below), though the dating is problematic. The Roman finds from Dunnicaer could fit the existing pattern, with material reaching the area c. AD 50-250 but rarely thereafter. Where Dunnicaer differs markedly is in the demonstration of a late Roman Iron Age structural phase, suggesting extended occupation into the late Roman Iron Age. This is rarely attested in the north-east. The finds from Dunnicaer thus show both the expected domestic material, rarer craft material in the form of the burnishers, and a range of Roman finds. The craft and import evidence are particularly important and both point to a site of regional significance. The Stones and Dating 
The five Pictish symbol stones found in the $19^{\text {th }}$ century are significant finds. Dunnicaer is one of only two coastal promontories with Pictish symbol stones south of the Dornoch Firth, the only other example being those from the 5.5 ha Pictish fort at Burghead. One of the most important elements of the symbol stones from Dunnicaer is the possibility to link the stones to a robustly dated site. As noted earlier, the Dunnicaer stones have been routinely identified as early examples (e.g. Alcock 1996, 2003, 372; Henderson and Henderson 2004, 171). Alcock rightly identified their form as unusual, being more like plaques suitable for setting in a wall-face than standing stones and indeed it is from a wall that they are reported as being found (Alcock and Alcock 1992, 281). It has been argued here that the traces of the rampart found on the southern side of the stack are the last vestiges of that wall. Modelling of the available radiocarbon dates suggests construction of this wall in the period cal AD 285-340 (68\% probability). They could have been added to the site after the main phase of occupation, but there is no evidence for use after the late fourth century AD, or the earliest fifth century AD at the very latest, with activity having ceased most probably by cal AD 375-425 (68\% probability). Indeed, the carvings on both sides of Dunnicaer No.5 is suggestive of reworking of the stone which is most likely to have occurred during the lifetime of the settlement. Overall, there is a strong case for the carving of the stones to be contemporary with the main phases of occupation and the third to fourth century dates for the rampart perhaps gives us one of the potential few fixed chronological points for the early development of the symbol tradition.

As highlighted in a recent article (Noble et al. 2018), the dating of Dunnicaer can shed new light on other sites with similar styles of carving, such as a small number of caves with a similar style of carving. Those from Sculptor's Cave, Covesea, Moray, with simple, small-scale designs (including a fish, crescents and V-rods, mirror-cases, a 
triple-oval and a 'flower' symbol) are close parallels for the Dunnicaer style of carvings. From inside the cave at Covesea, other than modern finds, none of the material culture suggests activity in the cave later than the fourth century AD. There is a collection of human remains that provide evidence for decapitation in the period cal AD 220-335 (Armit et al. 2011, 276), and there is also an important assemblage of Roman coins, metalwork and pottery, with the latest coin dated to AD 365 (Armit et al. 2011, 259). These dates are broadly contemporary with the construction of the wall at Dunnicaer. There are also Pictish symbols carved in a number of caves at East Wemyss, Fife. Very few in situ deposits have been found during excavations at the East Wemyss caves, but one cave, the Sliding Cave (which has carvings of a double-disc, serpents and a comb case) has been found to have an intact floor layer (with no evidence of later use) dated to cal AD 240-390 (95\% probability [NZA-20755]; $1726 \pm 30 \mathrm{BP})$, again broadly contemporary with the dates from Dunnicaer (Gibson and Stevens 2007).

Early dating for the symbol tradition has been proposed by earlier scholars such as Laing and Laing $(1984,266)$ and Thomas $(1961,45)$, but there were few radiocarbon dates to draw upon. Indeed, the chronology of the symbol tradition has been debated since the nineteenth century (Noble et al. 2018, table 1), and nearly all previous dating schemes have been based on art historical parallels rather than absolute dating from archaeological contexts. In his influential paper in the seminal volume Problem of the Picts (Wainwright 1955a) Stevenson argued that the most complex designs were the earliest based on the idea that there was a 'master' carver and symbol and that these designs tended to simplify or break down through time (Stevenson 1955, 102-3). However, in an archaeological context the typological scheme that Stevenson suggests, complex to simpler, is not one often found. There seems little to contest that the 
Dunnicaer and cave symbols are rudimentary in form, with the symbols represented by outline only with no internal decoration.

Relatively early dates for symbol stones with simple, unelaborated symbols is also suggested by evidence from Rhynie, Aberdeenshire, and Pool, Orkney. A series of symbol stones from Rhynie, Aberdeenshire, which show little in the way of internal decoration or elaboration to the symbols have been found in close association with a high status settlement of the late fourth to early sixth century $\mathrm{AD}$, with the dates including samples from a stone socket likely to be for one of the symbol stones. The later dates from Rhynie overlap with direct dating of an ox bone from Pool, Orkney. The bone from Pool is decorated with a crescent and V-rod of simple form (i.e. no internal decoration: [Hunter et al. 2007, 509]), and recent dating has produced a determination of cal AD 410-570 (SUERC-73735; $1570 \pm 33$ BP; 95\% probability) (cal AD 420-540; 68\% probability). Another decorated bone pin from Pool, with a doubledisc and Z-rod is contemporary, coming from a fifth to sixth century settlement phase (Noble et al. 2018, 1336).

The style of carving at the sites above contrasts with more elaborately decorated symbols found commonly amongst the symbol stone corpus. Importantly the style of carving of the symbols at Dunnicaer and the caves contrasts with the more elaborate designs of the crescent and V-rod found on a directly dated ox phalange from the Broch of Burrian Orkney, which has a date of AD 570-655 (95\% probability [UB-6923]; Clarke and Heald 2008). Recent dating of a human skeleton from Dairy Park, Dunrobin, Sutherland, indicates a similar likely dating horizon for a symbol stone where the symbols also have elaborate internal decoration -the skeleton produced a date of cal AD 565-640 (95\% probability [SUERC- 76203]; $1465 \pm 17$ BP, 68\% probability). The stone at Dairy Park was found directly above the position of the cairn during ploughing and is 
likely to be associated (contra Clarke 2007, 27). The evidence from Broch of Burrian and Dairy Park strongly suggests that the more elaborately decorated symbols are likely to be later in the sequence rather than earlier.

Overall, the dating from Dunnicaer has helped develop a new and more robust chronology and typology for the symbol tradition (Noble et al. 2018). In this recent study it is proposed that the unelaborated carvings of the type found at Dunnicaer, are likely to have originated in the late Roman Iron Age with the larger standing stone monuments bearing larger and more confidently carved symbols developing in the fifth to early sixth centuries, and yet more complex symbol designs with internal decoration in use by the late sixth century. Forsyth $(1997,93)$ suggested that the Dunnicaer and cave symbols were 'cursive' and thus their form may not relate to date, but the available dating evidence strongly suggests that the Dunnicaer examples are early examples in the tradition of symbol carving in north-east Scotland. In a wider context, a late Romanperiod origin places the Pictish symbol tradition more in line with other carving traditions in Europe. In Scandinavia, the use of runes has been traced back to at least the second century $\mathrm{AD}$, and in Ireland ogham goes back to at least the fourth century AD and probably earlier (Ahlqvist 1982, 8-10; Harvey 1987, 9; Odenstedt 1990, 169; Barnes 2012, 10-11; Charles-Edwards 2013, 119; Findell 2014, 15).

To look at the meaning and purpose of the stones at Dunnicaer, it is useful to look at the context of the Dunnicaer examples and the context of other Pictish stones. So much is lost at Dunnicaer that the context is difficult to grasp. Yet we know the stones are likely to have come from the southern rampart and the nineteenth century maps suggest that this part of the stack then survived to a similar extent to that of today. Thus, the stones must have come from the surviving part of the stack which must have always been at the landward end and at a part of the stack that is always likely to have 
narrowed. The presence of slot [078] in the western part of the upper terrace from what has been argued to represent an early gate or landward boundary suggests the stones were also close to at least one phase of the entrance. Recent excavations at Rhynie suggest the Craw Stane, a symbol stone decorated with a fish and 'Pictish beast', and at least one other stone were located at the entranceway to a fourth to sixth century high status enclosure complex and settlement. The other well-known Pictish fortified site with a rich corpus of sculpture is Burghead, Moray. At Burghead over 30 bull carvings are said to have been found (Oram 2007, 251). None have well-recorded contextual information and only six bull carvings survive today, nonetheless MacDonald (1862, 356) recounted that living witnesses attested to the discovery of the bull carvings towards the entrance of the upper fort. Hence, we can identify strong correlations with the context of the stones at each fort - at Dunnicaer, Rhynie and Burghead, carved stones were found in association with high status enclosures, and in each case near the entranceway.

Looking at the wider context, the other potential parallels for carved stone monuments at first millennium AD fortified sites are the carvings from Trusty's Hill, Kirjkcudbrightshire, and Dunadd, Argyll. At Trusty's Hill, a pair of Pictish-style symbols, a double-disc and Z-rod and a serpent and sword, are carved on an exposed face of outcropping rock at the entrance to the summit enclosure of an early medieval fort (Toolis and Bowles 2017, 1). The excavators argue that the carvings date to the main occupation horizon of the fort - the late sixth to early seventh century AD (Toolis and Bowles 2017, 105; though see Forsyth and Thickpenny in the same volume who argue for a later date). At Dunadd, one of the most prominent forts of Dál Riata, there is the carving of a boar, an ogham inscription, a footprint and a rock-cut basin, found close to the entrance of the summit citadel (Lane and Campbell 2000, 18). At Dunadd the date 
of the carvings is uncertain. The boar has been suggested to date anywhere between the fifth to ninth century (Lane and Campbell 2000, 20); the ogham sixth century or later (Forsyth 2000) and the footprint stone, anywhere from the early to high medieval period, with an early medieval dating thought to be the most likely (Lane and Campbell 2000, 248-249). As to function, Lane and Campbell speculate that the carvings at Dunadd were used in royal inauguration ceremonies associated with the Dál Riatan overkingship (Lane and Campbell 2000, 247-249). The symbols and rock cut basin at Trusty's have similarly been proposed to be part of inauguration rites (Toolis and Bowles 2017, 137).

A role in inauguration is a stretch for the Dunnicaer symbol stones, given their relatively crude form and lack of further contextual information, but the similar context for their placement to the examples from prominent post-Roman power centres is certainly intriguing. With regards to Pictish symbols there have been multiple interpretations of their meaning over the last century and more (Noble et al. 2018, table 1), but the current consensus suggests that the symbol system probably a naming system, albeit un-deciphered (Samson 1992; Forsyth 1997; Lee 2010; Lee et al. 2010). This is supported by the monuments themselves, some of which show individuals 'labelled' by symbols - such as the Dunfallandy monument in Perthshire (Allen and Anderson 1903, 38; Stevenson 1955, 123; Noble et al. 2018, 1333). The Dunnicaer examples may have been an early experimentation with that system, identifying particularly important powerful individuals who were associated with the fort at Dunnicaer by name or lineage. In this respect, the symbol stones may have literally branded the fort in monumental form with the symbols expressing the power and identity of the occupants of the fort, the finds from which, suggest they are likely to have been local or regional leaders of elevated status. 


\section{Historical Context and Interpretation}

The dates for Dunnicaer - beginning probably sometime in the first or second century $\mathrm{AD}$ and activity having ended by the late fourth or early fifth at the latest - puts the fort in an interesting historical context. The start date obviously broadly coincides with Roman military invasion and intervention in northern Britain and the end towards the end of Roman rule in southern Britain. Roman interest in Scotland can be traced to 70s and 80s AD, with the Romans, under the command of Agricola, advancing into Scotland, and by 83 AD marching to the Moray Firth, and probably in 84 AD gaining a decisive victory at the Battle of Mons Graupius, before then retreating back to the TyneSolway area (Maxwell 1989, 27, 103-4, 121-7; Fraser 2005, 9), at least according to Agricola, an account of the governor's campaigns written in AD 98 by his son-in-law Tacitus (Ogilvie and Richmond 1967, 10-12). Tacitus suggests that during Agricola's invasion, native groups (civitates) resisting the Romans came together and made treaties with each other (Agricola 27.2, Ogilvie and Richmond 1967, 109-10). This alliance was possibly destroyed by the defeat at Mons Graupius, but the Roman presence seems to have promoted the formation of larger political units, since Dio Cassius wrote that the Britons north of frontier had merged into two groups by about A.D. 200 (Cary 1927: 262-3).

It is within this context of military invasion and the consolidation of native polities that we might fruitfully situate the establishment of new power centres and fortified enclosures, an act that was clearly relatively infrequent given the rarity of fortified sites dating from this period. The emergence of Dunnicaer likely occurred in the first or second century AD when Roman military intervention had reached and then retreated from north-east Scotland, with the area perhaps witnessing further Roman intervention in the area during the Severan campaigns. The very unusual finds of 
Roman material culture from Dunnicaer shows that the occupants were well connected, obtaining Roman goods through raiding, trading (direct or indirect) or diplomatic bribes (Hunter 2007; Blackwell et al. 2018). Arguably it is through this contact that the community at Dunnicaer and others in eastern Scotland may have developed the symbol tradition (Noble et al. 2018). Contact with the Roman Empire would have exposed the Picts to written language and inscriptions on monumental sculpture. Hence, like runes in Scandinavia and ogham in Ireland, the Pictish symbols are likely to have been created beyond the frontier in response to Roman influence (Noble et al. 2018, 1344). However, like Gaelic- and Germanic-speaking groups, the Picts did not directly adopt the alphabet - they invented their own system, unlike ogham or runes, the symbol system appears to have been non-alphabetic in origin. It may have been an even closer proximity to Roman rule that made the peoples north of the frontier in Britain all the more aware of their non-Roman status and the adoption of a non-alphabetic system may have 'proclaimed an independence' (Barnes 2012, 11), from the Mediterranean world in ways more emphatic than in Scandinavian and Irish contexts. The symbol stones at Dunnicaer, appear to have been erected or re-used within a rampart built on the south side (perhaps mirroring the placement of inscriptions on Roman military monuments). This rampart enclosed a promontory settlement with multiple structures within. The occupants within the site lived at least at times within this promontory enclosure and inside a range of structures, at least some of them sub-rectangular in form stood. These sub-rectangular structures attest to changing architectural traditions amongst the native groups who built them - and indicate further probable Roman influence in their lives and lifestyles.

The continued occupation into the third and fourth centuries AD, and possibly the early fifth century AD is rare on any Scottish settlement. With regard to our limited 
written sources for this period, the late Roman Iron Age has often been seen as a period of political consolidation of native groups in face of continuing threats from a Roman presence. In the mid-second century AD fourteen groups are located in Ptolemy's Geography north of the Clyde-Forth line, but in Roman sources in the later second century only two groups are mentioned - the Caledonians and Maeatae. Dio Cassius' account of the wars of Septimius Severus included the statement that 'In Britain there are two very large nations, the Caledonians and the Maeatae, and the names of the others have become included in these' (Cary 1927: 262-3). Dio Cassius recounts that the Caledonians broke their agreements with the Romans and assisted the Maeatae in causing trouble, leading to the Romans buying off the Maeatae (Cary 1927: 216-17). Treaties were then made, creating a new peace with the Romans, though both the Maeatae and Caledonii had to cede a substantial amount of territory (Cary 1927: 41). These new agreements appear to have been successful for there is no evidence of conflict between the Romans and the peoples to the north until the end of the third century.

The textual sources that survive have generally been interpreted to suggest political consolidation north of the frontier in the Roman period that extended into the third and fourth centuries with the emergence of the Picts (e.g. Mann 1974, 40-1; Breeze 1996, 115-117). While a panegyric of 310 referring to 'Caledonians and other Picts' (Mann and Penman 1996, 50-1) might suggest that the Pictish identity was simply a gloss, Ammianus Marcellinus, referring to events of 367-70 says 'at that time the Picts [were] divided into two tribes, called Dicalydones and Verturiones' (xxvii.8,5: Rolfe 1935, Vol. III, 52-3). This indicates the Picts constituted two main groups, much like the arrangements in the early third century though under different names. Ammianus Marcellinus (xx.1.1: Rolfe 1935, 2-3) in AD 360 refers to 'raids of the 
savage tribes of the Scots and the Picts, who had broken the peace that had been agreed upon, were laying waste the regions near the frontiers, so that fear seized the provincials'. Then in 367 the Picts were involved in the 'barbarian conspiracy', a prolonged episode of co-ordinated raiding on Roman Britain in which the Picts colluded with the Attacotti, Scotti, Franks and Saxons.

However, Fraser Hunter in a number of studies (e.g. 2007, 52-54, 2010, 96, 2014, 206; See also Blackwell et al. 2018, 19-44) has argued that the mid-third century onwards was one of crisis north of the frontier rather than one of political consolidation. He argues that the Romans in the second century had built up particular groups through political favouritism and directed exchange, but that these relationships ceased in the third century leading to political collapse (See also Cruickshanks and Hunter above). He has pointed to the significant fall in the number of Roman artefacts found beyond the frontier, particularly north of the Forth in the period AD 250-400 and linked this to other changes in material culture north of the Forth and east of the Atlantic zone: the end of the construction and often use of roundhouse architecture and souterrains in eastern Scotland, a lack of settlements of Roman Iron Age date, and a change in artefact types away from regionally distinctive artefact styles to more utilitarian forms (Hunter $2007,46-48 ; 2010,100)$.

There is no doubting that the settlement record for north-east Scotland from the third century onwards becomes diffuse and difficult to identify. However, the form of architecture from Dunnicaer, while difficult to reconstruct, shows why we may have so few settlements from this period - earthfast elements were rare and the building types from Dunnicaer is an architectural tradition that is unlikely to be identifiable in the intensively ploughed lowlands of eastern Scotland. Thus, the lack of settlements from this period may not indicate a crisis in third to fourth century native society, though 
there was certainly change (the lack of settlement from this period may also limit the discovery of Roman artefacts from this period in North-east Scotland). At Dunnicaer, there is a lack of definite fourth century Roman material, but our chronological resolution for some artefacts types is poor and we have also lost so much of the site to erosion. It is also not necessarily the case that the lack of Roman artefacts, especially the silver and other fine objects that tended to come north before the mid-third century (Hunter 2007, 24-7), would have caused the dramatic social changes that Hunter has hypothesised. As Hunter states, any coinage that found its way north was not used as currency, but as objects which marked status (Hunter 2007, 23-5, 2010, 98). While some of the items had practical functions, their number was low, so they may not have been overly significant to the local economy, though Hunter suggests that silver, unlike tableware and dress accessories which could be sourced locally, was not so easily replaceable (Hunter 2014, 209). In native society the primary function of imported silver and other objects was to enhance the status of those who possessed them, as they could be used for display and as gifts to supporters and allies (Hunter 2007, 23-5). When, elites ceased to obtain these items, there were clear attempts to maintain the same pattern. In central and southern Scotland, for example, a number of examples are known of denarii coin moulds, for copying Roman third century coins (Hunter 2007, 25). However, without these items, attempts would have also presumably been made to produce other items for gift exchange also. For instance, at Birnie, where there were hoards of Roman coins, there is also evidence for the smelting and smithing of iron on a large scale (Hunter 2007, 32).

Thus, there were other routes to power and there could certainly have been benefits to the end of Roman material flowing north. We do not know the details of the agreements that the Romans made with the Maeatae, Caledonii and others, but 
elsewhere such treaties could involve regular tributes of weapons, produce and people (often for the Roman army) (Breeze 1982, 139). The only information that we do have is that in 197 and probably in ca. 210 or 211 , the Caledonii broke their agreements with Rome by supporting the Maeatae, in the latter case against the Romans. Part of Roman diplomacy was designed to play off groups against each other and to prevent larger groups emerging. Therefore, Roman support came at a cost, in terms of political capital and material resources, shifting both away from where they would have otherwise been more profitably employed. As a result, what may look like a crisis in material culture in north-east Scotland in the late Roman period may in practical terms have made little difference or indeed made the polities of the north stronger, perhaps explaining the more effective attacks on the Romans after AD 300. Indeed, the adoption of subrectangular forms of architecture and the adoption of an inscribed tradition that must have been influenced by the literate cultures of the Empire (Noble et al. 2018), suggests that Roman practices continued to be adopted and modified by elites north of the frontier. Thus, while there was certainly change in the late Roman Iron Age it was not a period necessarily characterised by crisis, but one in which native societies began to organize themselves in different ways and, as evidenced by the barbarian conspiracy, began to take the fight to the Empire more effectively than previously. Roman sources suggest native groups were engaged in long-range campaigning and raiding, with the social and political circumstances of this period perhaps conducive to the development of war bands that would have contributed to the increasing effectiveness of native attacks on the Empire (cf. Hunter 2010, 103-104, 2014, 209).

Dunnicaer endured into the fourth century and there is little evidence for change in the form or success of the settlement here, and despite the absence of late Roman artefacts there is no reason to believe that the occupation was impoverished in its later 
phases prior to its desertion. Indeed, it may be that the site at Dunnicaer continued to thrive and could have even been involved in some of the fourth century raids on the Roman Empire. The coastal location of Dunnicaer, with bays on either side of the fort would make an ideal staging post for sea raiding. The scale and reach of the raiding that the Picts were involved in during events such as the barbarian conspiracy of 367 suggests that these raids involved maritime action, the likes of which could have been launched from promontory forts of the kind found along the east coasts of Aberdeenshire, Angus and Fife. Certainly, by the sixth century maritime power appears to have been an intergral part of Pictish power with Adomnan's reference (II.42; Anderson and Anderson 1991: 166-7) to a sub-relugus of Orkney in King Brude's court strongly suggestive of Pictish rulers dominating maritime networks of power that extended over significant parts of northern Scotland and the Isles. Dunnicaer is a forerunner of the sixth/seventh century fort at Burghead, Moray, the seventh to eighth century fort of Green Castle, Portknockie, and presumably Dunnottar. These were all major important Pictish promontory forts. In reference to Burghead, maritime power has been identified as a significant component of the fort's function and status (e.g. Shepherd 1993, 79), and the power of the occupants at the earlier site of Dunnicaer, may have similarly relied on the sea.

\section{Conclusions}

Dunnicaer has produced unexpected insights into the development of fortified settlement in eastern Scotland in the Roman Iron Age and unusual evidence for continuity through this period. The presence of rare and unusual Roman finds provides evidence of contacts with the Empire far north of the frontier and the settlement evidence highlights changes in architecture in a region where settlement has been previously difficult to document. The shift to rectangular or sub-rectangular traditions 
of building may itself have been influenced by contact with the Roman world. The ability to contextualise the five Pictish symbol stones found at the site in the nineteenth century is also an important element of the findings. Both the symbol stones and the enclosed status of the settlement at Dunnicaer are hallmarks of the forms of elite centres that came to dominate north-east Scotland on a larger scale from the fifth century to the end of the first millennium AD (Noble et al. 2013, Noble et al. 2019). Recent scholarship has suggested that Pictish ethnogenesis was brief and late, a phenomenon of the seventh century AD (Fraser 2009, 43-67; Woolf 2017). However, the development of a fortified settlement at Dunnicaer and the evidence it provides for early innovation of the symbol tradition suggests that elements of what we traditionally use to identify Pictish period archaeology (and rightly or wrongly associate with particular early medieval identities and language groups) occurred in the Late Roman period, in the same era the Picts are first mentioned in Roman sources. The potentially early dating of the symbol tradition is particularly interesting for forms of writing and symbolic systems have long been linked to the development of more complex societies in a variety of contexts around the world (e.g. Postgate et al.1995, 459). The shared use of this symbolic system across eastern and northern Scotland in the late Roman period and certainly by the fifth century (Noble et al. 2018, 1341-2), is in precisely the areas that seventh and eighth century historical sources locate the Pictish kingdoms. Dunnicaer itself did not endure into the fifth century or at least not far into the fifth century, but we know that by the seventh century a major power centre at Dunnottar was in existence (Fraser 2009, 214). It may have been in the fifth century that the high-status community at Dunnicaer shifted to the larger promontory of Dunnottar, though obviously that remains speculative without any confirmed early medieval phases yet identifiable at the larger promontory of Dunnottar. 


\section{Acknowledgements}

Thanks to Dunecht Estate for granting permission to access and investigate Dunnicaer. Duncan Paterson of North-east Mountaineering very ably got the team up on top and ensured our safety at all times. Many thanks to the brave diggers Michael Stratigos, Claire Christie, Vanessa Rees, Rob Lenfert, Oskar Sveinbjarnarson, Grace Woolmer, Anni Tolppanen, John Graham, Victoria Wilson, Katie South, Juudit Gross, Scott White, Gemma Cruickshanks, John Harrison, Sarah Elliot, Jeff Oliver and Juliette Mitchell (and Duncan). Bruce Mann and Caroline Palmer kindly provided scans of aerial photographs of Dunnicaer from the Aberdeenshire SMR records. The project was funded by Don and Elizabeth Cruickshank through the University of Aberdeen Development Trust, by Aberdeenshire Council and through grant funding from the Strathmartine Trust.

\section{References}

Ahlqvist, A. 1982. The Early Irish Linguist: An Edition of the Canonical Part of the Auraicept na n-Éces. Helsinki: Societas Scientiarum Fennica.

Alcock, L. 1996. "Ur-symbols in the Pictograph-system of the Picts.” Pictish Arts Society 9: 2-5.

Alcock, L. 2003. Kings and Warriors, Craftsmen and Priests in Northern Britain AD 550-850. Edinburgh: Society of Antiquaries of Scotland.

Alcock, L. and E. A. Alcock. 1992. "Reconnaissance Excavations on Early Historic Fortifications and Other Royal Sites in Scotland, 1974-84; 5: A, Excavations and Other Fieldwork at Forteviot, Perth-shire, 1981; B Excavations at Urquhart Castle, Invernessshire, 1983; C, Excavations at Dunnottar, Kincardineshire, 1984." Proceedings of the Society of Antiquaries of Scotland 122: 215-87. 
Alcock, L., E. Alcock and S. Foster. 1986. "Reconnaissance Excavations on Early Historic Fortifications and other Royal Sites in Scotland, 1974-84:1, Excavations near St Abb's Head, Berwickshire, 1980." Proceedings of the Society of Antiquaries of Scotland 116, 255-79.

Allen, R. J. and J. Anderson. (1903) 1993. The Early Christian Monuments of Scotland. Balgavies: Pinkfoot Press.

Anderson, M. O. (1973) 1980. Kings and Kingship in Early Scotland. Edinburgh: Scottish Academic Press.

Anderson, A.O. and M. O. Anderson (ed. and trans.). 1991. Adomnán 's Life of Columba. Oxford: Oxford University Press.

Armit, I., R. Schulting, C. J. Knüsel and I. A. G. Shepherd. 2011. "Death, Decapitation and Display? The Bronze Age and Iron Age Human Remains from the Sculptor's Cave, Covesea, North-east Scotland." Proceedings of the Prehistoric Society 77: 251-78. Ashmore, P. J. 1999. "Radiocarbon Dating: Avoiding Errors by Avoiding Mixed Samples.” Antiquity 73: 124-130.

Barnes, M. P. 2012. Runes: A Handbook. Woodbridge: Boydell Press.

Barry, T. B., S. Diamond, T. D. Shanley, M. Scannell and E. Soergel-Harbison. 1981. “Excavations at Dunbeg Promontory Fort, County Kerry, 1977." Proceedings of the Royal Irish Academy 81: 295-329.

Bidwell, P. 1994. “The Pottery.” In Excavations at South Shields Roman Fort. Vol. 1., edited by Bidwell, P. and S. Speak, 206-42. Newcastle: The Society of Antiquaries of Newcastle Upon Tyne.

Bidwell, P. and A. Croom, 2002. "The Roman pottery.” In 'Excavations at Castle Garth, Newcastle upon Tyne, 1976-92 and 1995-96; the excavation of the Roman Fort', Snape M. and P. Bidwell. Archaeologica Aeliana 31, 139-72. 
Blackwell, A., M. Goldberg. and F. Hunter. 2017. Scotland's Early Silver. Edinburgh:

National Museum Scotland.

Bond, J. M. 2007. “The Mammal Bone.” In Excavations at Pool, Sanday. A Multi-

Period Settlement from Neolithic to Late Norse Times, edited by Hunter, J., 207-262.

Kirkwall: The Orcadian.

Breeze, D. J. 1982. The Frontiers of Roman Britain. London: Batsford.

Breeze, D. J. 1996. Roman Scotland: Frontier Country. London: B. T. Batsford.

Brock, F., T. Higham, P. Ditchfield and C. Bronk Ramsey. 2010. "Current Pretreatment

Methods for AMS Radiocarbon Dating at the Oxford Radiocarbon Accelerator Unit

(ORAU).”Radiocarbon 52 (1): 103-112.

Bronk Ramsey, C. 2009. "Bayesian Analysis of Radiocarbon Dates.” Radiocarbon 51

(1): $337-360$.

Brown, I. 2009. Beacons in the landscape. The hillforts of England and Wales. Oxford:

Windgather Press/Oxbow Books.

Buck C. E., W. G. Cavanagh and C. D. Litton. 1996. Bayesian Approach to Interpreting Archaeological Data. Chichester: John Wiley \& Sons, Ltd.

Campbell, E. 2007. Continental and Mediterranean Imports to Atlantic Britain and Ireland, AD 400-800. York: Council for British Archaeology.

Campbell, L. 2016. "Proportionalising Practices in the Past: Fragments beyond the Frontier." In Creating Material Worlds: The Uses of Identity in Archaeology, edited by E. Pierce, A. Russell, A. Maldonado, and L. Campbell, 215-239. Oxford: Oxbow.

Carver, M., J. Garner-Lahire and C. Spall. 2016. Portmahomack on Tarbat Ness: Changing Ideologies in North-East Scotland, Sixth to Sixteenth Century AD. Edinburgh: Society of Antiquaries of Scotland.

Cary, E. (ed. and trans.). 1927. Dio's Roman History, Vol. IX. London: Heinemann. 
Charles-Edwards, T. M. 2013. Wales and the Britons, 350-1064. Oxford: Oxford University Press.

Cherish 2019. Climate, Heritage and Environments of Reefs, Islands and Headlands EU Funded Project. Accessed 8 Nov 2019. http://www.cherishproject.eu/en/

Childe, V. G. and Forde, C. 1932. "Excavations in Two Iron Age Forts at Earn's Heugh, near Coldingham." Proceedings of the Society of Antiquaries of Scotland 66: 152-83.

Clarke, D. V. 2007. "Reading the Multiple Lives of Pictish Symbol Stones.” Medieval Archaeology 51 (1): 19-39.

Clarke, D. V. and A. Heald. 2008. “A New Date for 'Pictish' Symbols.” Medieval Archaeology 52 (1): 291-310.

Close-Brooks, J. 1986. "Excavations at Clatchard Craig, Fife." Proceedings of the Society of Antiquaries of Scotland 116: 117-184.

Cool, H. E. M. 1992. “The Vessel Glass.” In “Carlisle: Excavation of a Section of the Annexe Ditch of the First Flavian Fort, 1990.”, edited by Caruana, I. Britannia 23 (1992), 63-68.

Cool, H. E. M. and J. Price. 1995. Roman Vessel Glass from Excavations in Colchester, 1971-85. Colchester Archaeological Report Vol. 8. Colchester: Colchester Archaeological Trust.

Cool, H. E. M. and J. Price. 1998. “The Vessels and Objects of Glass.” In Roman Castleford - Excavations 1974-85. Vol 1: The Small Finds. Yorkshire Archaeology 4., edited by Cool, H. E. M. and C. Philo, 141-181. Wakefield: West Yorkshire Archaeology Service.

Crane, P. and K. Murphy. 2010. "The Excavation of a Coastal Promontory Fort at Porth y Rhaw, Solva, Pembrokeshire, 1995-98." Archaeologia Cambrensis 159: 53-98. 
Crone, A. and E. Hindmarch. 2016. Living and Dying at Auldhame: The Excavation of an Anglian Monastic Settlement and Medieval Parish Church. Edinburgh: Society of Antiquaries of Scotland.

Cruickshanks, G. and A. Sheridan. Forthcoming. "The Pottery from Sculptor's Cave, Covesea." In The Sculptor's Cave, Covesea, edited by Armit, I. and L. Büster.

Daffy, S. 2013. "Irish and Roman Relations: A Comparative Analysis of the Evidence for Exchange, Acculturation and Clientship from South-east Ireland.” PhD diss., University of Galway.

Darling, M. J., ed. 1994. Guidelines for the Archiving of Roman Pottery. London: Study Group for Roman Pottery.

Dowling, G. 2011. "The Architecture of Power." In Landscapes of Cult and Kingship, edited by Schot, R., C. Newman and E. Bhreathnach, 213-231. Dublin: Four Courts Press.

Dunne, L. 2014. Monitoring of Works at Dunbeg Coastal Promontory Fort, Dingle Peninsula - September 2014.

http://www.ldarch.ie/news/14070986

Dynamic Coast 2019. "Dynamic Coast: Scotland's Coastal Change Assessment." http://www.dynamiccoast.com/

Findell, M. 2014. Runes. London: British Museum.

Forsyth, K. 1997. “Some Thoughts on Pictish Symbols as a Formal Writing System.” In The Worm, the Germ and the Thorn, edited by Henderson, I. and D. Henry, 85-98. Brechin: Pinkfoot Press.

Forsyth, K. 2000. “The Ogham Inscription at Dunadd.” In Lane, A. and E. Campbell 2000: 264-272. 
Fraser, J. 2005. The Roman Conquest of Scotland. The Battle of Mons Graupius AD 84.

Stroud: The History Press.

Fraser, J. E. 2009. From Caledonia to Pictland: Scotland to 795. Edinburgh: Edinburgh University Press.

Gibson, C. and C. Stevens. 2007. "Iron Age and Pictish Activity at Wemyss Caves, Fife." Tayside and Fife Archaeological Journal 13: 91-99.

Gibson, A. and A. Woods. 1990. Prehistoric Pottery for the Archaeologist. Leicester: Leicester University Press.

Harden, D. B. 1947. "Camulodunum, the Glass.” In Camulodunum: First Report on the Excavations at Colchester, 1930-1939 (Reports of the Research Committee of the Society of Antiquaries London 14)., edited by Hawkes, C. F. C. and M. R. Hull, 287307. Oxford: University Press.

Harvey, A. 1987. "Early Literacy in Ireland: The Evidence from Ogham.” Cambridge Medieval Celtic Studies 14: 1-15.

Henderson, I. 1958. "The Origin Centre of the Pictish Symbol Stones." Proceedings of the Society of Antiquaries of Scotland 91: 44-60.

Henderson G. and I. Henderson. 2004. The Art of the Picts: Sculpture and Metalwork in Early Medieval Scotland. London: Thames and Hudson.

Heslop, D. H. 2008. Patterns of Quern Production, Acquisition and Deposition. A Corpus of Beehive Querns from Northern Yorkshire and Southern Durham. Leeds: Yorkshire Archaeological Society.

Holmes, N. M. M. 2006. "Two denarius hoards from Birnie, Moray", The British Numismatic Journal 76: 1-44. 
Hunter, F. 1998. “Lead.” In 'Excavation Of A Timber Round-House And Broch At The Fairy Knowe, Buchlyvie, Stirlingshire, 1975-83', Main, L. Proceedings of the Society of Antiquaries of Scotland 128, 52-6.

Hunter, F 2001 'Roman and native in Scotland: new approaches', J Roman Archaeology 14, 289-309Hunter, F. 2001. "Roman and Native in Scotland: New Approaches.” Journal of Roman Archaeology 14, 289-309.

Hunter, F. 2007. Beyond the Edge of the Empire: Caledonians, Picts and Romans. Rosemarkie: Groam House Museum.

Hunter, F. 2010. "Beyond the Frontier: Interpreting Late Roman Iron Age Indigenous and Imported Material Culture." In Finds from the Frontier: Material Culture in the 4th - 5th Centuries, edited by Collins, R. and L. Allison-Jones, 96-109. York: Council for British Archaeology.

Hunter, F. 2014. "Looking over the Wall: The Late and Post-Roman Iron Age North of Hadrian's Wall." In AD 410: The History and Archaeology of Late and Post-Roman Britain, edited by Haarer, F. K., 206-215. London: Roman Society.

Hunter, F. 2015. "Craft in context: artefact production in later prehistoric Scotland." In Scotland in Later Prehistoric Europe, edited by Hunter, F. and I. A. G. Ralston, 22546. Edinburgh: Society of Antiquaries of Scotland.

Hunter, F. 2016. "Discussion of the Iron Age Phase: A Context for Roman Finds on Deeside.” In The Use and Reuse of Stone Circles. Fieldwork at Five Scottish Monuments and its Implications, edited by Bradley, R. and C. Nimura, 53-5. Oxford: Oxbow.

Hunter, F. and Cruickshanks, G. In prep. "The Artefacts from Castle Craig.” In Excavations at Castle Craig, Perthshire, edited by Poller, T. 
Hunter, J., J. M. Bond and A. N. Smith. 2007. Investigations in Sanday, Orkney.

Volume 1: Excavations at Pool, Sanday. Kirkwall: Orcadian.

Hydrographic Office. 1884. "Stonehaven Bay.” Hydrographic Office. Accessed Jan 10

2019. https://maps.nls.uk/coasts/admiralty/3018

Ingemark, D. 2016. “The Roman vessel glass from Leckie Broch, Stirlingshire.” In

MacKie, E. W. Brochs and the Empire: The impact of Rome on Iron Age Scotland as seen in the Leckie broch excavations, 157-161. Oxford: Archaeopress.

Ingemark, D. 2014. Glass, Alcohol and Power in Roman Iron Age Scotland. Edinburgh:

National Museum of Scotland.

Ingemark, D. 2016. “The Roman Vessel Glass from Leckie Broch, Stirlingshire.” In

Brochs and the Empire: The Impact of Rome on Iron Age Scotland as Seen in the Leckie

Broch Excavations, edited by MacKie, E. W., 157-161. Oxford: Archaeopress.

Isings, C. 1957. Roman Glass from Dated Finds. Groningen: J. B. Wolters.

Kennedy, K. 2017. “Feasting in Iron Age Scotland.” Master's diss., University of the Highlands and Islands.

Kilbride-Jones, H. E. 1935. “An Aberdeenshire Iron Age Miscellany 2. Objects in the Possession of Mr Alexander Shand, Longcroft, Rhynie." Proceedings of the Society of Antiquaries of Scotland 69 (1934-35): 448-54.

Kinghorn, R. 1935. "Unrecorded Berwickshire Antiquities, Being the Chalmers-Jervise Prize Essay for 1933.” Proceedings of the Society of Antiquaries of Scotland 69 (19345): $157-67$.

Laidlay, J. W. 1870. "Notice of an Ancient Structure and Remains from a 'Kitchenmidden', on an Isolated Rock near Seacliff, East Lothian." Proceedings of the Society of Antiquaries of Scotland 8: 372-77. 
Laing, L. and J. Laing. 1984. "The Date and Origin of the Pictish Symbols."

Proceedings of the Society of Antiquaries of Scotland 114: 261-276.

Lane, A. and E. Campbell. 2000. Dunadd: An Early Dalriadic Capital. Oxford: Oxbow.

Lee, R. 2010. "The Use of Information Theory to Determine the Language Character Type of Pictish Symbols.” Scottish Archaeological Journal 32 (2): 137-176.

Lee, R., P. Jonathan and P. Ziman. 2010. "Pictish Symbols Revealed as a Written Language Through Application of Shannon Entropy." Proceedings of the Royal Society 10: $1-16$.

Lethbridge, T. C. and H. E. David. 1930. "Excavation of a House-site on Gateholm, Pembrokeshire.” Archaeologia Cambrensis 85, 366-74

Lock, G. and I. B. M. Ralston. 2017. Atlas of Hillforts. Accessed 1 September 2019. https://hillforts.arch.ox.ac.uk/.

MacDonald, J. 1862. "Historical Notes of the 'Broch' or Burghead, in Moray, with an Account of its Antiquities." Proceedings of the Society of Antiquaries of Scotland 4: $321-69$.

Mac Airt, S. and G. Mac Niocaill, eds. and trans. 1983. The Annals of Ulster (To A.D. 1131). Part I: Text and Translation. Dublin: Dublin Institute for Advanced Studies. Mack, A. 2007. Symbols and Pictures: The Pictish Legacy in Stone. Brechin: Pinkfoot Press.

MacSween, A. 2008. “The Prehistoric Pottery.” In Cook, M. and L. Dunbar. Rituals, Roundhouses and Romans, 17-89. Edinburgh: Scottish Trust for Archaeological Research.

MacSween, A. Forthcoming. "The Prehistoric Pottery." In Culduthel: An Iron Age Craft Centre, Hatherley, C. and R. Murray. Edinburgh: Society of Antiquaries of Scotland. Mainland, I. In prep. The Faunal Remains from Rhynie. 
Mann, J. C. 1974. “The Northern Frontier after A.D. 369.” Glasgow Archaeological Journal 3: 34-42.

Mann, J. C. and R. G. Penman. 1996. Literary Sources for Roman Britain. Lactor 11. London: London Association of Classical Teachers.

Marshall, D. N. 1964 "Report on Excavations at Little Dunagoil.” Transactions of the Buteshire Natural History Society 16: 3-69.

Maxwell, G. 1989. The Romans in Scotland. Edinburgh: J Thin.

McGill, C. 2001. "Pottery.” In “Survey and excavation at Tarradale, Highland.”, edited by Gregory, R. A. and G. D. B. Jones, Proceedings of the Society of Antiquaries of Scotland 131, 241-66.

McGill, C. 2005. "Native Pottery." In "Redcastle, Lunan Bay, Angus: The Excavation of an Iron Age Timber-lined Souterrain and a Pictish Barrow Cemetery.”, edited by Alexander, D., Proceedings of the Society of Antiquaries of Scotland 135: 41-118. McLaren, D. 2016. “The Pottery.” In "Prehistoric Settlement Patterns in the North-east of Scotland: Excavations at Grantown Road, Forres 2002-2013.”, edited by Cook, M., Scottish Archaeological Internet Reports 61: 26-37.

McLaren, D. and F. Hunter. 2008. "New Aspects of Rotary Querns in Scotland." Proceedings of the Society of Antiquaries of Scotland 138: 105-128.

Moloney, C., M. Hastie, T. Holden, J. Roberts, J. Franklin, and D. Henderson, D. 2001. "New evidence for the origins and evolution of Dunbar: excavations at the Captain's Cabin, Castle Park, Dunbar, East Lothian”. Proceedings of the Society of Antiquaries of Scotland 131: 283-317.

Morrison, J. 2003. “Castle Dykes, Dunglass (Cockburnspath Parish), Evaluation.”, Discovery and Excavation in Scotland 4: 114. 
NRHE. National Monuments Record for Scotland. Accessed 10 Dec 2018.

https://canmore.org.uk/.

Noble, G., M. Goldberg, and D. Hamilton. 2018. "The Development of the Pictish

Symbol System: Inscribing Identity beyond the Edges of Empire.” Antiquity 92 (365): $1329-1348$.

Noble, G., M. Gondek, E. Campbell and M. Cook. 2013. "Between Prehistory and History: The Archaeological Detection of Social Change Among the Picts." Antiquity 87 (338): 1136-1150.

Noble, G., M. Gondek, E. Campbell, N. Evans, D. Hamilton, A. Ross and S. Taylor. 2019. “A Powerful Place of Pictland: Interdisciplinary Perspectives on a Post-Roman Power Centre.” Medieval Archaeology 63: 59-64.

Odenstedt, B. 1990. On the Origin and Early History of the Runic Script. Stockholm: Almqvist and Wiksell.

Ogilvie, R. M. and I. Richmond, eds. 1967. Cornelii Taciti: De Vita Agricolae. Oxford: Clarendon Press.

Oram, R. 2007. “Capital Tales or Burghead Bull?” In Fil Súil Ngais: A Grey Eye Looks Back: A Festschrift in Honour of Colm Ó Baoill, edited by Arbuthnot, S. and K. Hollo, 241-62. Ceann Drochaid: Clann Tuirc.

O’Sullivan, A., F. McCormick, T. R. Kerr and L. Harney. 2014. Early Medieval Ireland, AD 400-1100: The Evidence from Archaeological Excavation. Dublin: Royal Irish Academy Monograph.

Owen, O.A. 1992. "Eildon Hill North". In Hillforts of southern Scotland, edited by Rideout, J.S., O.A. Owen and E. Halpin, 21-72. Edinburgh: AOC (Scotland) Ltd and Historic Scotland. 
Page, M., T. Driver, L. Barker, K. Murphy and P. Crane. 2009. "Prehistoric Defended Enclosures: Remote Sensing 2008-09." Unpublished report, Dyfed Archaeological Trust.

PCRG (Prehistoric Ceramic Research Group). (1991) (1995) 2011. “The Study of Later Prehistoric Pottery: General Policies and Guidelines for Analysis and Publications.” Prehistoric Ceramic Research Group Occasional Paper No.1 and No.2.

Peacock, D. 2013. The stone of life: querns, mills and flour production in Europe up to c. $A D$ 500. Southampton: Monographs in Archaeology new series 1.

Pelling, R. 1990. "Brackla Excavation of a Ditched Enclosure.” Manchester Archaeological Bulletin 5: 12-19.

Perry, D. R. 2000. Castle Park, Dunbar: Two Thousand Years on a Fortified Headland. Edinburgh: Society of Antiquaries of Scotland.

Pollak, S. 2018. "Future of Precarious Kerry Fort Dunbeg Hangs in the Balance." https://www.irishtimes.com/news/environment/future-of-precarious-kerry-fort-dunbeghangs-in-the-balance-1.3346234

Postgate, N., T. Wang and T. Wilkinson. 1995. "The Evidence for Early Writing: Utilitarian or Ceremonial?" Antiquity 69: 459-80.

Price, J. 1985. “The Roman Glass.” In Inchtuthil. Britannia Monograph Series 6, edited by Pitts, L. F. and J. K. St Joseph, 303-312.

Price, J. 1990. “Roman Vessel and Window Glass.” In A Roman, Anglian and Medieval site at Blackfriars Street, Carlisle: Excavations 1977-79, edited by McCarthy, M. R., 163-179. Kendal: Cumberland and Westmorland Antiquarian and Archaeological Society.

Price, J. and S. Cottam. 1998. Romano-British Glass Vessels: A Handbook. Practical Handbook in Archaeology 14. York: Council for British Archaeology. 
Ralston, I. B. M. 1977. “Dunnicaer.” Discovery and Excavation in Scotland, 19.

Ralston, I. B. M. 1980. “The Green Castle and the Promontory Forts of North-east Scotland." Scottish Archaeological Forum 10: 27-40.

Ralston, I. B. M. 1987. "Portknockie: Promontory Forts and Pictish Settlement in the North-East." In The Picts: A New Look at Old Problems, edited by Small, A., 15-26. Dundee: University of Dundee.

Ralston, I. B. M. 2004. The Hill-Forts of Pictland since 'The Problem of the Picts'. Rosemarkie: Groam House.

Ralston, I. B. M. and N. Fojut. 1977. "Rathven, Portnockie: Green Castle Promontory Fort." Discovery and Excavation in Scotland, 9.

Ralston, I. B. M. and Inglis, J. 1984. Foul Hordes: The Picts in the North-East and Their Background. Aberdeen: University of Aberdeen Anthropological Museum. RCAHMS. 1982. The Archaeological Sites and Monuments of South Kincardine, Kincardine and Deeside District, Grampian Region. The archaeological sites and monuments of Scotland series 15. Edinburgh: RCAHMS.

RCAHMS. 2008. The Royal Commission on the Ancient and Historical Monuments of Scotland. The Pictish Symbols of Scotland. Edinburgh: RCAHMS.

Reimer, P. J., E. Bard, A. Bayliss, J. W. Beck, P. G. Blackwell, C. Bronk Ramsey, C. E. Buck et al. 2013. "IntCal13 and Marine13 Radiocarbon Age Calibration Curves 050,000 Years cal BP.” Radiocarbon 55: 1869-1887.

Ritchie, A. 1996. Orkney, Exploring Scotland's Heritage. Edinburgh: Stationary Office. Ritchie, J. 1915. "Notes on Some Aberdeenshire Sculptured Stones and Crosses." Proceedings of the Society of Antiquaries of Scotland 49: 1914-15.

Robertson, A. S. 1970. "Roman Finds From Non-Roman Sites in Scotland: More Roman 'Drift' in Caledonia.” Britannia 1: 198-226. 
Rolfe, J. C., ed. and trans. 1935-1952. Ammianus Marcellinus. 3 vols. London: Heinemann.

Rütti, B. 1991. "Early Enamelled Glass.” In Two Centuries of Art and Invention (Occasional papers from the Society of Antiquaries of London 13), edited by Newby, M. and K. Painter, 122-136. London: Society of Antiguaries of London.

Sahlen, D. 2009. "Working With Clay." In Beakers, Bones and Birnie: Proceedings of the Moray Society Annual Conference. Elgin: The Moray Society/ Elgin Museum.

Sahlen, D. Forthcoming. "Petrographic Report on Pottery from Sculptor's Cave.” In The Sculptor's Cave, Covesea, edited by Armit, I. and L. Büster.

Samson, R. 1992. "The Reinterpretation of the Pictish Symbols." Journal of the British Archaeological Association 145 (1): 29-65.

SCHARP. 2018. Scotland's Coastal Heritage at Risk. Accessed 9 Jan 2018. http://scharp.co.uk/

Schmidt, E. 1972. Atlas of Animal Bones for Prehistorians, Archaeologists and Quaternary Geologists. Amsterdam: Elsevier Science Publishers.

Seetah, K. 2016. Digest 7.1 "Summary Report on Animal Bones." In Portmahomack on Tarbert Ness, edited by Carver, M., J. Garner-Lahire and C Spall, D131-D135. Edinburgh: Society of Antiquaries.

Shepherd, I. A. G. 1993. "The Picts In Moray.” In Moray Province and People, edited by Sellar, W. H. D., 75-90. Edinburgh: University of Edinburgh.

Simpson, W. D. 1937. Dunnottar Castle: Historical and Descriptive. Aberdeen: Wyllie. Simpson, D. 1996. "Excavation of a Kerbed Funerary Monument at Stoneyfield, Raigmore, Inverness, Highland, 1972-3.” Proceedings of the Society of Antiquities of Scotland 126: 53-86. 
Smith, C. 1994. “Animal Bone Report (and Microfiche).” In Howe: Four Millennia of Orkney Prehistory, edited by Ballin Smith, B., 139-153. Edinburgh: Society of Antiquaries.

Stiner, M. C., S. L. Kuhn, S. Weiner and O. Bar-Yosef. 1995. "Differential Burning, Recrystallization, and Fragmentation of Archaeological Bone." Journal of Archaeological Science 15: 223-237.

Stevenson, R. B. K. 1955. “Pictish Art.” In Wainwright 1955a: 97-128.

Stuart, J. 1856. Sculptured Stones of Scotland. Aberdeen: Spalding Club.

Stuart, J. 1867. Sculptured Stones of Scotland: Volume 2. Edinburgh: Spalding Club.

Stuiver, M. and R. S. Kra. 1986. "Editorial Comment.” Radiocarbon 28 (2B): ii.

Stuiver, M. and H. A. Polach. 1977. "Reporting of ${ }^{14}$ C data." Radiocarbon 19 (3): 355363.

Stuiver, M. and P. J. Reimer. 1986. “A Computer Program for Radiocarbon Age Calibration." Radiocarbon 28 (2B): 1022-1030.

Stuiver, M. and P. J Reimer PJ. 1993. "Extended ${ }^{14} \mathrm{C}$ Data Base and Revised CALIB 3.0 ${ }^{14}$ C Calibration Program.” Radiocarbon 35 (1): 215-230.

Taylor, S., ed. 2000. Kings, Clerics and Chronicles in Scotland, 500-1297: Essays in Honour of Marjorie Ogilvie Anderson on the Occasion of her Ninetieth Birthday.

Dublin: Four Courts Press.

Taylor, S. 2008 "The Toponymic Landscape of the Gaelic Notes in the Book of Deer." In Forsyth 2008a, 275-308.

Taylor, S. 2011. "Pictish Place-names Revisited.” In Pictish Progress: New Studies on Northern Britain in the Early Middle Ages, edited by Driscoll, S. T., Geddes, J. and Hall, M. A., 67-118. Leiden: Brill. 
Taylor, S., with G. Márkus. 2006. The Place-Names of Fife Vol. 1 (West Fife between Leven and Forth). Donington: Emerald Group Publishing.

Taylor, S., with G. Márkus. 2009. The Place-Names of Fife Vol. 3 (St Andrews and the East Neuk). Donington: Emerald Group Publishing.

Taylor, S., with G. Márkus. 2012. The Place-Names of Fife Vol. 5 (Discussion, Glossaries and Edited Texts, with Addenda and Corrigenda of Volumes 1-4).

Donington: Emerald Group Publishing.

Thomas, C. 1961. "The Animal Art of the Scottish Iron Age and its Origins." The Archaeological Journal 117: 14-64.

Thomas, C. 1963. "The Interpretation of the Pictish Symbols." The Archaeological Journal 120: 31-64.

Thomson, A. 1859. "Notice of Sculptured Stones found at 'Dinnacair' a Rock in the Sea, near Stonehaven." Proceedings of the Society of Antiquaries of Scotland 3: 69-75.

Tomber, R. and Dore, J. 1998. The National Roman Fabric Reference Collection A Handbook. London: MoLAS.

Toolis, R. and C. Bowles. 2017. The Lost Dark Age Kingdom of Rheged: The Discovery of a Royal Stronghold at Trusty's Hill, Galloway. Oxford: Oxbow.

Wainwright, F. T. 1955b. “The Picts and the Problem.” In Wainwright (ed.) 1955a, 153.

Wallace, C. 2008. "The Roman Pottery." In Rituals, Roundhouses and Romans Excavations at Kintore 2000-2006 Volume 1 Forest Road, Cook, M. and Dunbar, L., 189-90. Edinburgh: STAR. 
Wallace, C. 2019. “The samian sherd.” In 'Context for a carnyx: excavation of a longlived ritual site at Leitchestown, Deskford, Moray, north-east Scotland', Hunter, F. Archaeological Journal 176/2: 231-335.

Wallace, C. Forthcoming a. "The Samian.” In Darkness Visible: The Sculptor's Cave, Covesea, from the Bronze Age to the Picts, edited by Armit, I. and L. Büster. Edinburgh: Society of Antiquaries of Scotland.

Wallace, C. Forthcoming b. "The Roman Pottery.” In Excavations at an Iron Age Power Centre: Birnie, Moray, edited by Hunter, F., 1998-2011.

Walton Rogers, P. 2007. Cloth and Clothing in Early Anglo-Saxon England AD 450700. York: Council for British Archaeology.

Watson, W. J. (1926) 2011. The Celtic Place-names of Scotland. Edinburgh: Birlinn. Watt, J. C. 1914. The Mearns of Old: A History of Kincardine from the Earliest Times to the Seventeenth Century. Edinburgh and Glasgow.

Wessex Archaeology. 2010. "Watery Bay and Gateholm Island, Pembrokeshire, Wales.” Salisbury: Unpublished Report, Wessex Archaeology. https://www.wessexarch.co.uk/sites/default/files/77508_Gateholm_report.pdf Willis, S. 1998. "Iron Age and Roman Pottery.” In Main, L. 'Excavation of a timber round-house and broch at the Fairy Knowe, Buchlyvie, Stirlingshire, 1975-83', Proceedings of the Society of Antiquaries of Scotland 128: 21-31

Wilson, E. M. 1980. "Excavations at West Mains of Ethie, Angus." Proceedings of the Society of Antiquaries of Scotland 110: 114-121.

Woolf, A. 2007. From Pictland to Alba, 789-1070. Edinburgh: Edinburgh University Press.

Woolf, A. 2017. "On the Nature of the Picts.” Scottish Historical Review XCVI (2): 214-17. 
